\title{
Consensus-based multidimensional due diligence of fintech-enhanced green energy investment projects
}

\author{
Wei Liu' ${ }^{*}$, Youfa Sun ${ }^{1}$, Serhat Yüksel ${ }^{2}$ and Hasan Dinçer ${ }^{2^{*}}$ (1)
}

\author{
${ }^{*}$ Correspondence: \\ weiliugdut@sina.com; \\ hdincer@medipol.edu.tr \\ 1 School of Economics \\ and Commerce, Guangdong \\ University of Technology, \\ Guangzhou, People's \\ Republic of China \\ 2 The School of Business, \\ Istanbul Medipol University, \\ İstanbul, Turkey
}

\begin{abstract}
The purpose of this study is to provide a hybrid group decision-making approach to evaluate fintech-based financial alternatives for green energy investment projects. First, the multidimensional factors of due diligence for fintech-based financing alternatives of green energy investment projects are identified. In this regard, the balanced scorecard perspectives are considered. Next, consensus-based group decision-making analysis is performed. Second, impact-relation directions for fintech-based financing alternatives of green energy investment projects are defined. For this purpose, the spherical fuzzy Decision-Making Trial and Evaluation Laboratory (DEMATEL) methodology is applied. The novelty of this study is its proposal of a new outlook to due diligence of fintech-project financing for renewable energy investments by using the group and integrated decision-making approaches with spherical fuzzy DEMATEL. The findings indicate that customer expectations are the most essential factor for the revenue sharing and rewarding models. Additionally, this study identified that organizational competency plays the most important role with respect to the peer-to-business debt model. In contrast, the conclusion was reached that financial returns have the greatest importance for the equity sharing model.
\end{abstract}

Keywords: Fintech-based project financing, Green energy investments, Balanced scorecard, Due diligence of projects, Group decision making, Spherical fuzzy sets

\section{Introduction}

One of the most prominent energy consumption problems is air pollution. Using fossil fuels results in a significant amount of carbon gas being released into the atmosphere. Because this situation causes very serious health problems, countries attempt to take actions to solve this problem. In this context, the importance of green energy has increased, especially in recent years. Countries have aimed to use natural resources, such as the sun and wind, to avoid harming the environment during the energy consumption process (Zhong et al. 2020). When these energy types are used, carbon emissions from the electricity generation process are very low. Another advantage of these energy types is that they contribute to countries' energy independence. Countries will be able to produce their own energy by using green energy 
(Dinçer and Yüksel 2019a, b). In this framework, the current account deficit problem of countries that do not have to import energy from abroad might decrease.

In contrast, green energy projects have some drawbacks. In this process, the most problematic issue is the high initial costs. Because green energy projects are investments with complex structures, expensive materials might need to be used during these projects' installation phases. This situation weakens the motivation of investors toward these projects (Bertheau 2020) and indicates that financing is very important in green energy projects. In this context, the risk exists that the cost of the project might reach an uncontrollable level if the needed fund is provided ineffectively. Therefore, when financing green energy projects, many different issues should be simultaneously considered.

The aforementioned issues lead to the understanding that fintech applications are very important in reducing the efficiency of green energy investments. In the financial sector, fintech refers to innovative technologies (Kou et al. 2021), and advances in technology strongly affect this sector (Boot et al. 2021). Fintech applications enable the financial sector to easily, effectively, and quickly provide financial services, and many related benefits can be discussed. For example, faster delivery of financial services increases customer satisfaction (Zha et al. 2020), which contributes to increases in green energy investments. Moreover, fintech applications facilitate green energy investors' access to needed funds at a low cost (Bu et al. 2021). Thus, increasing green energy investments, which are very important for the economic development of the country, will be possible.

Mentioning different fintech-based financing alternatives is possible. The revenue sharing model refers to royalty payments based on sales performance. In this model, the total income is distributed to shareholders. The main advantage of this method is that less sharing occurs with shareholders when the company's sales volume is low (Yang et al. 2019a, b). In contrast, with respect to the peer-to-business debt model, companies borrow given a risk premium. The biggest advantage of this method is that the lending institution is not a partner to the company. However, these debts must be paid even if the business is not profitable (Alzoubi 2018). Moreover, regarding the equity sharing model, equity shares are provided with shareholders' rights-that dividend payments depend on the company's performance is an important advantage of this method. However, this method causes new partners to enter the business, and these partners have the power to control the business (Fianto et al. 2018). Finally, the rewarding model provides products and services of projects at preorder prices (Harish et al. 2020).

Furthermore, a successful fintech system requires that internal and external due diligence be effective. The due diligence process includes controlling the performance of some key points during the process (Degerli 2019). First, in this regard, the target company's financial situation should be evaluated effectively. An appropriate understanding of the company's financial performance contributes to the fintech system's effectiveness (Boratyńska 2019). Within this framework, companies' commercial due diligence should be conducted. For this purpose, companies' performance in meeting customer expectations and generating innovative products should be considered (Fenwick et al. 2018). In contrast, technical due diligence includes assessing the company's technological power. In this context, the sufficiency of the company's information technology system should be examined (Gozman et al. 2018). 
During the due diligence evaluation, different factors should obviously be analyzed at the same time, such as customer, finance, and technical effectiveness. Hence, this analysis is understood to be similar to the balanced scorecard evaluation. The balanced scorecard methodology aims to evaluate a company's or department's performance in multiple ways. In this context, analyzing both financial and nonfinancial aspects of the company is considered this method's most important advantage (Benková et al. 2020). The balanced scorecard approach has four different dimensions: finance, customer, internal process, and learning and growth. Regarding the financial dimension, companies' balanced sheets and income statements are evaluated (Hu et al. 2019a, b). Moreover, the customer dimension provides information on how the company is successful in meeting customer expectations (Delen et al. 2020). Additionally, the internal process dimension includes the effectiveness of the communication between departments. Finally, the learning and growth dimensions focus on companies' growth capacities. Therefore, the due diligence evaluation is viewed as having strong similarities with the balanced scorecard approach (Moraga et al. 2020).

To address the uncertainties, the first unresolved effort was made by Zadeh (1996). Since then, fuzzy sets have been applied in many areas, such as decision making (Ekel 2002), medical diagnosis (Yao and Yao 2001), and pattern recognition (Pedrycz 1990). Many extensions to fuzzy sets have been introduced, such as rough sets (Pawlak 1982), soft sets (Molodtsov 1999), intuitionistic fuzzy sets (Atanassov 1999), linear diophantine fuzzy sets (Riaz and Hashmi 2019), bipolar valued fuzzy sets (Lee 2000), bipolar soft sets (Shabir and Naz 2013; Mahmood 2020), and picture fuzzy sets (Cuong and Kreinovich 2013) in recognition of the importance of the fuzzy of fuzzy sets. Although all of these extensions have their advantages, the notion of picture fuzzy set has gained much more attention from researchers relative to others; see Riaz et al. (2021), Mahmood and Ali (2020), and Jan et al. (2019). However, the dependency of the membership grade causes the abstinence grade and nonmembership grade to fail when the sum of these grades exceeds 1. Mahmood et al. (2019) introduced the notion of spherical fuzzy sets to overcome this problem. This notion received significant attention by researchers given its diverse nature (Ullah et al. 2020; Ashraf and Abdullah 2019; Ali et al. 2020a,b). Therefore, keeping with the view of the importance and applications of spherical fuzzy sets in real-life problems in information sciences, medical diagnosis, and decision making, we have decided to use spherical fuzzy sets to handle the problem.

This study aims to evaluate fintech-based financial alternatives of green energy investments by considering balanced scorecard perspectives. In this framework, a novel two-stage model has been generated. In the first stage, the consensus results of multidimensional due diligence for fintech-based financing alternatives of green energy investment projects are calculated. For this purpose, consensus-based group decision-making methodology is considered. The second phase includes the generation of the impactrelation directions of consensus-based multidimensional due diligence for fintech-based financing alternatives of green energy investment projects. Within this context, the spherical fuzzy DEMATEL methodology is used. During this process, balanced scorecard perspectives are weighted for four different fintech-based financial alternatives.

The most important contribution of this study is identifying the significant points for green energy investment companies according to different fintech-based financing 
alternatives using a novel methodology. Additionally, this proposed model has some novelties. First, considering a consensus-based group decision-making methodology provides some advantages. During the decision-making process, the biggest problem is that experts can have different opinions of the factors (Liu and Pedrycz 2020), decreasing the effectiveness of this process. This problem can be minimized using a feedback mechanism for the consensus methodology (Zhang et al. 2018). Second, another important advantage of this proposed model is considering spherical fuzzy sets during the evaluation process to enable consideration of membership, nonmembership, and hesitancy parameters (Mathew et al. 2020). Therefore, more appropriate results can be achieved with the help of these fuzzy sets (Kutlu Gündoğdu and Kahraman 2019).

Furthermore, using the balanced scorecard methodology provides the opportunity to include both financial and nonfinancial issues during the evaluation process (Benková et al. 2020). Thus, a more effective due diligence evaluation can be made. In addition, a comparison in the literature of similar approaches shows that the DEMATEL model has some superiority. This model can be used to generate an impact-relation map of the criteria (Zhang et al. 2020; Yuan et al. 2021; Kou et al. 2021). Therefore, the causal relationship among the items can also be identified, in addition to weighting the criteria, by considering the DEMATEL methodology (Fang et al. 2021; Yuan et al. 2020; Meng et al. 2021a, b). Additionally, the results of this study provide significant strategies for both policymakers and investors regarding the financial alternatives of green energy investments. Moreover, using multicriteria decision-making models to solve this problem helps achieve more effective results (Suroso et al. 2021; Basilio et al. 2018). Given the advantages of these methods, many different researchers used these techniques in the literature for similar subjects (Marqués Marzal et al. 2020; Mitkova and Mlynarovič 2019).

The remainder of this study is constructed as follows. In section two, a comprehensive literature evaluation was conducted. Hence, gaps in the literature can be identified. The third section of this study includes the methodological information about the approaches used in this study. Additionally, the details of the proposed model are provided in this section. The fourth section provides information about the analysis results. In the final section, the conclusion and discussion are presented.

\section{Literature review}

In this section, first, the literature is reviewed regarding green energy finance. Second, some studies on fintech applications are summarized. Finally, the results of the literature review are discussed.

\section{Literature on green energy finance}

Green energy investments have high initial costs. This situation poses a major obstacle to increasing these investments (Plutshack et al. 2019; Iryna et al. 2020). Therefore, the necessary state support should be given to these projects in a significant number of the studies (Mirzania et al. 2019; Heuër 2017). In this framework, some researchers argued that green energy investors should be provided with tax cuts. Karimi et al. (2018), Sangroya and Nayak (2017), and Yang et al. (2019a, b) also reached the conclusion that tax reduction has a powerful impact on improvements to green energy investment projects. 
In contrast, Grafström et al. (2020) focused on the effectiveness of green energy projects in 12 different European countries. The result of the panel data analysis identified that governments should provide the necessary support to research and development studies on green energy projects. Additionally, Jin et al. (2019), Stucki (2019), and Hughes and Meckling (2017) also underlined the significance of this issue for green energy investment projects. Geddes et al. (2018) aimed to examine green energy investment projects in Australia, the UK, and Germany. Within this framework, interviews were conducted for 52 different green energy investment companies in these countries. The analysis results indicate that the most effective way to finance these investments is through government support. For this purpose, they recommended that a state investment bank should be developed that can provide necessary fund support to these companies. Similarly, Zhang (2020) and Zhou et al. (2020) highlighted that state banks should play a more effective role in financing green energy investment projects.

According to some researchers, government support will not be sufficient to increase green energy investments. In this context, private banks operating in the country should also play an active role in this process (Opeyemi et al. 2019; Khan and Singh 2017; Tan et al. 2019). Because the principal and interest payments are predetermined, regulating the company's cash flow can be much easier (Kutan et al. 2018; Taghizadeh-Hesary et al. 2020). In contrast, even if green energy investments fail, this debt must be paid on time. Therefore, this is considered one of the biggest disadvantages of bank loans because high interest rates increase the amount of debt (Chang et al. 2019; Vand et al. 2019). Egli et al. (2018) focused on the financing conditions for green energy technologies. For this purpose, 133 representative utility-scale photovoltaic and onshore wind projects in Germany were considered. They underlined that bank loans are mainly preferred to finance these green energy projects. Hence, they claimed that high interest rates negatively affect the development of these projects. In addition to this study, Lyu and Shi (2018) researched financing efficiency assessments for the green energy industry. In this context, an evaluation was conducted with the help of the data envelopment analysis that indicated that the companies should mainly provide debt financing relative to equity financing. Moreover, Best (2017) attempted to examine ways to improve green energy projects. The largest barrier behind the improvements of these projects is the high initial cost. Therefore, the conclusion reached is that private bank loans should be increased to support wind energy projects.

In contrast, some researchers also underlined the importance of effective risk management in the financing process of green energy investments. Mazzucato and Semieniuk (2018) evaluated the financing alternatives of green energy investments. They highlighted the significance of risk management in this framework. For this purpose, they reached the conclusion that private investors mainly prefer low-risk investments. Hence, if the clean energy projects have long maturity and high initial costs, public financing sources should be considered. Moreover, Polzin et al. (2019) reviewed the effectiveness of the policies regarding improvements in green energy projects. For this purpose, the risks and returns are evaluated. Additionally, in this regard, 96 different studies in the literature are examined and concluded that necessary policy implications should be designed for the development of private financing for green energy projects. Because this situation minimizes the risks in this process, the financing costs can be minimized 
more effectively. Similarly, Sweerts et al. (2019) examined the green energy potential of African countries and defined that the cost effectiveness of these projects should be provided to develop green energy investments. For this purpose, investors should prioritize implementations of financial de-risking. Moreover, Steffen (2018) examined the importance of project finance for green energy investment projects. In this study, nonrecourse project finance techniques are recommended to improve these projects. They claimed that the risks of these projects could be handled more effectively with the help of this implementation.

\section{Literature on fintech implementations}

Fintech refers to using technology to improve financial services. The most important goal in this process is to increase customer satisfaction through facilities provided by technological developments (Lee and Shin 2018; Sun et al. 2021; Sarkodie et al. 2021). This situation is predicted to improve financial services. Such advantages enable fintech applications to significantly contribute to increases in investments in the country (Gomber et al. 2018; Dorfleitner et al. 2017a, b; Meng et al. 2021a, b). Anshari et al. (2019) focused on the impacts of fintech applications on the performance of the agriculture industry. They identified that these implementations provide innovative financial solutions for the broader agriculture ecosystem. Therefore, they concluded that fintech applications have a powerful impact on the sustainability of the agricultural industry. Additionally, Gimpel et al. (2018) claimed that fintech implementations are very helpful to satisfy customer expectations. Moreover, Fosso Wamba et al. (2020) identified that fintech has a positive influence on supply chain performance. However, Jagtiani and Lemieux (2019), Hu et al. (2019a, b), and Dorfleitner et al. (2017a, b) underlined the importance of data security for the sustainable success of fintech implementations.

\section{Literature on methodology}

Multicriteria decision-making models became more popular, especially in recent years. Many researchers considered these approaches and focused on different industries, such as banking (Liang et al. 2019; Dincer 2019; Dinçer and Yüksel 2018), tourism (Nilashi et al. 2019; Wu et al. 2018; Tian et al. 2020) and (Illbahar et al. 2018; Rajak and Shaw 2019; Li et al. 2017). In some studies, these methods were also considered for the energy industry (Teo et al. 2020; Alkan and Albayrak 2020; Thangaramya et al. 2019; Zhao et al. 2021). Moreover, the balanced scorecard approach was also preferred in many studies for different purposes. For example, Owusu (2017), Dinçer and Yüksel (2019a, b), and Dinçer et al. (2019) evaluated the banking sector's performance with the assistance of the balanced scorecard approach. Additionally, some studies considered the balanced scorecard approach for the healthcare industry (Leksono et al. 2019; Rahimi et al. 2017; Janbazi et al. 2019). Furthermore, Dinçer et al. (2017), Khairat (2017), and Karun Kumar and Kesava Rao (2020) examined the performance of the airline industry given this methodology.

\section{Results of the literature review}

The literature analysis enabled some important results to be reached. First, green energy investments have become very popular, especially in recent years. A significant increase 
was observed in the number of studies conducted on this subject. In addition, an examination of these studies led to the understanding that the most important obstacle to the development of green energy projects is high costs. In this context, these costs should be reduced through efficient financing resources. In this context, fintech applications play a very important role in achieving this goal. These applications make it possible to contribute to the reduction of high costs-one of the most important problems of green energy investments. However, the number of studies in the literature on fintech applications in green energy investments is quite limited. This study aimed to evaluate fintech-based financial alternatives for green energy investment projects. In this context, a novel model was proposed that includes two different stages. First, the consensus results of multidimensional due diligence for fintech-based financing alternatives of green energy investment projects are constructed. For this purpose, consensus-based group decision-making methodology is considered. Second, the next stage includes illustrating the impact-relation directions of consensus-based multidimensional due diligence for fintech-based financing alternatives of green energy investment projects. In this scope, the spherical fuzzy DEMATEL methodology is considered.

\section{Methodology}

This section first includes the details of group decision making with consensus. Subsequently, the spherical fuzzy sets are discussed. After that, necessary information is given with respect to the DEMATEL approach. In the final part, the proposed model is detailed.

\section{Group decision making with consensus}

One of the most significant difficulties regarding the decision-making process is the different expert evaluations. This situation has a negative influence on the effectiveness of this process. Therefore, the concept of consensus plays a key role in solving this problem. With respect to the group decision-making approach, the feedback mechanism is implemented to reach more appropriate results. In this context, a fuzzy preference relation $(\mathrm{P})$ indicates the relation degrees of the factors as described in Eq. (1). In this equation, $\mu_{p}$ represents the membership function (Xu et al. 2019).

$$
P=\left(P_{i k}\right) \text { and }, P_{i k}=\mu_{p}\left(x_{i}, x_{k}\right),(\forall i, k \in\{1, \ldots, n\})
$$

In the next step, the corresponding fuzzy preferences (CP) are calculated using Eq. (2).

$$
C P_{i k}=\frac{\sum_{j=1 ; i \neq k \neq j}^{n}\left(C P_{i k}\right)^{j 1}+\ldots+\left(C P_{i k}\right)^{j(n-1)}}{(n-1) *(n-2)}
$$

After that, the consistency levels (CL) are computed with the help of Eqs. (3) and (4) (Dong et al. 2018).

$$
\begin{aligned}
& C L_{i k}=1-\left(\frac{2 *\left|C P_{i k}-P_{i k}\right|}{(n-1)}\right) \\
& C L_{i}=\frac{\sum_{k=1 ; i \neq k}^{n}\left(C L_{i k}+C L_{k i}\right)}{2(n-1)}
\end{aligned}
$$


The global consistency level (GCL) is calculated using Eq. (5) (Zhang et al. 2018).

$$
G C L=\frac{\sum_{i=1}^{n} C L_{i}}{n}
$$

Subsequently, similarity matrixes are calculated with the help of Eqs. (6) and (7). In these equations, $e_{h}$ and $e_{l}$ provide information about the pairs of experts, and $\phi$ represents the aggregation function.

$$
\begin{aligned}
& S M_{i k}^{h l}=1-\left|P_{i k}^{h}-P_{i k}^{l}\right| \\
& S M_{i k}=\phi\left(S M_{i k}^{h l}\right)
\end{aligned}
$$

In addition, the global consensus degrees (CR) among the decision makers are calculated using Eq. (8) (Liu and Pedrycz 2020).

$$
C R=\frac{\sum_{i=1}^{n} \frac{\sum_{k=1 ; k \neq i}^{n}\left(S M_{i k}+S M_{k i}\right)}{2(n-1)}}{n}
$$

Moreover, consensual degrees $\left(Z_{i k}^{h}\right)$ are computed using Eq. (9).

$$
Z_{i k}^{h}=(1-\delta) * C L_{i k}^{h}+\delta *\left(\frac{\sum_{l=h+1}^{n} S M_{i k}^{h l}+\sum_{l=1}^{h-1} S M_{i k}^{l h}}{n-1}\right)
$$

In this framework, $\delta$ indicates the control parameter of consistency and consensus degrees. This value is defined as 0.75 in this study to identify the importance of consensus between decision makers. Subsequently, the collective fuzzy preference relations $\left(P_{i k}^{c}\right)$ are computed using Eqs. (10)-(12) (Zhang et al. 2018). Within this framework, $\sigma$ provides information about the permutation of $\{1, \ldots, m\}, Z_{i k}^{\sigma(h)} \geq Z_{i k}^{\sigma(h+1)}$, $\forall h=1, \ldots, m-1$. Moreover, $\left\langle Z_{i k}^{\sigma(h)}, P_{\sigma(i)}\right\rangle$ states a two-tuple with $Z_{i k}^{\sigma(h)}$ having the $h$ th largest value in $\left\{Z_{i k}^{1}, \ldots, Z_{i k}^{m}\right\}$.

$$
\begin{aligned}
& P_{i k}^{c}=\Phi w\left(Z_{i k}^{1}, P_{i k}^{1}, \ldots, Z_{i k}^{m}, P_{i k}^{m}\right)=\sum_{h=1}^{m} w_{h} * P_{i k}^{\sigma(h)} \\
& \left.w_{h}=Q(h / n)-Q(h-1) / n\right) \\
& (r)= \begin{cases}0 & \text { ifr }<a \\
\frac{r-a}{b-a} & \text { ffa } \leq r \leq b \\
1 & \text { fr }>a\end{cases}
\end{aligned}
$$

In the following step, the proximity levels $\left(P P_{i k}^{h}\right)$ and the relation among criteria $\left(\operatorname{Pr}^{h}\right)$ are generated as in Eqs. (13) and (14).

$$
P P_{i k}^{h}=1-\left|P_{i k}^{h}-P_{i k}^{c}\right|
$$




$$
\operatorname{Pr}^{h}=\frac{\sum_{i=1}^{n} \frac{\sum_{k=1 ; k \neq i}^{n}\left(P P_{i k}^{h}+P P_{k i}^{h}\right)}{2(n-1)}}{n}
$$

Additionally, the consensus control level (CCL) is calculated. This value is used to determine whether a consensus is reached by the decision makers. In this process, Eq. (15) is considered (Xu et al. 2019).

$$
C C L=(1-\delta) * G C L+\delta * C R
$$

Within this context, threshold value $(\gamma)$ is used, and this value is generally considered to be 0.85 . During this process, the feedback mechanism is implemented to enable the values to be revised. This process is continued until the CCL value rises above the threshold. Within this scope, the values of EXPCH, ALT, and APS are calculated as in Eqs. (16)-(18) (Dong et al. 2018).

$$
\begin{aligned}
& \text { EXPCH }=\left\{h \mid(1-\delta) * C L^{h}+\delta * P r^{h}<\gamma\right\} \\
& A L T=\left\{(h, i) \mid e_{h} \in E X P C H \wedge(1-\delta) * C L_{i}^{h}+\delta * \frac{\sum_{k=1 ; k \neq i}^{n}\left(P P_{i k}^{h}+P P_{k i}^{h}\right)}{2(n-1)}<\gamma\right\} \\
& A P S=\left\{(h, i, k) \mid(h, i) \in A L T \wedge(1-\delta) * C L_{i k}^{h}+\delta * P P_{i k}^{h}<\gamma\right\}
\end{aligned}
$$

\section{Spherical fuzzy sets}

Spherical fuzzy sets $\left(\tilde{A}_{S}\right)$ are the generalized form of Neutrosophic and Pythagorean fuzzy numbers. The aim is to use the hesitancy degree of the fuzzy set with these sets. Within this context, $\mu$ provides information on the membership, and $v$ indicates the nonmembership functions. Additionally, the hesitancy parameter is shown as $\pi$. Equations (19) and (20) demonstrate the details of this process (Kutlu Gündoğdu and Kahraman 2019).

$$
\begin{aligned}
& \tilde{A}_{S}=\left\{u,\left(\mu_{\tilde{A}_{S}}(u), v_{\tilde{A}_{S}}(u), \pi_{\tilde{A}_{S}}(u)\right) \mid u \in U\right\} \\
& 0 \leq \mu_{\tilde{A}_{S}}^{2}(u)+v_{\tilde{A}_{S}}^{2}(u)+\pi_{\tilde{A}_{S}}^{2}(u) \leq 1, \quad \forall_{u} \in U
\end{aligned}
$$

Similarly, Fig. 1 indicates the details of the membership, nonmembership, and hesitant degrees (Ashraf et al. 2019).

In this framework, $X_{1}$ and $X_{2}$ state two different universes. Moreover, $\tilde{A}_{S}=\left(\mu_{\tilde{A}_{S}}, v_{\tilde{A}_{S}}, \pi_{\tilde{A}_{S}}\right)$ and $\tilde{B}_{S}=\left(\mu_{\tilde{B}_{S}}, v_{\tilde{B}_{S}}, \pi_{\tilde{B}_{S}}\right)$ represent two spherical fuzzy sets. Equations (21)-(24) provide information about this process (Mathew et al., 2020).

$$
\tilde{A}_{S} \oplus \tilde{B}_{S}=\left\{\left(\mu_{\tilde{A}_{S}}^{2}+\mu_{\tilde{B}_{S}}^{2}-\mu_{\tilde{A}_{S}}^{2} \mu_{\tilde{B}_{S}}^{2}\right)^{\frac{1}{2}}, v_{\tilde{A}_{S}} \nu_{\tilde{B}_{S}}\left(\left(1-\mu_{\tilde{B}_{S}}^{2}\right) \pi_{\tilde{A}_{S}}^{2}+\left(1-\mu_{\tilde{A}_{S}}^{2}\right) \pi_{\tilde{B}_{S}}^{2}-\pi_{\tilde{A}_{S}}^{2} \pi_{\tilde{B}_{S}}^{2}\right)^{\frac{1}{2}}\right\}
$$




\section{$\pi$}

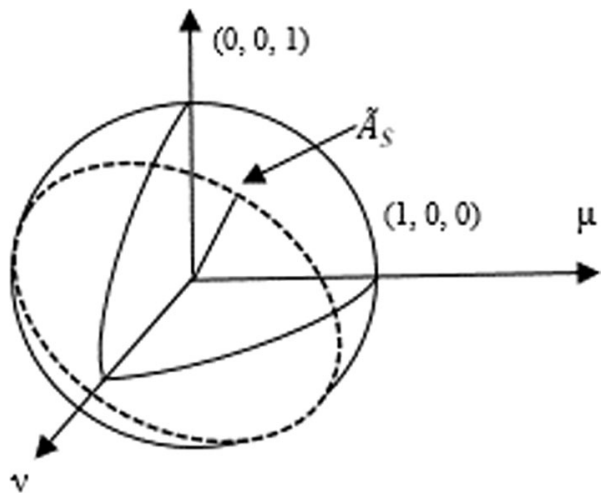

Fig. 1 Illustration of spherical fuzzy sets

$$
\begin{aligned}
& \tilde{A}_{S} \otimes \tilde{B}_{S}=\left\{\left(\mu_{\tilde{A}_{S}} \mu_{\tilde{B}_{S}},\left(v_{\tilde{A}_{S}}^{2}+v_{\tilde{B}_{S}}^{2}-v_{\tilde{A}_{S}}^{2} v_{\tilde{B}_{S}}^{2}\right)^{\frac{1}{2}},\right.\right. \\
&\left.\left(\left(1-v_{\tilde{B}_{S}}^{2}\right) \pi_{\tilde{A}_{S}}^{2}+\left(1-v_{\tilde{A}_{S}}^{2}\right) \pi_{\tilde{B}_{S}}^{2}-\pi_{\tilde{A}_{S}}^{2} \pi_{\tilde{B}_{S}}^{2}\right)^{\frac{1}{2}}\right\} \tilde{A}_{S} \otimes \tilde{B}_{S} \\
&=\left\{\left(\mu_{\tilde{A}_{S}} \mu_{\tilde{B}_{S}},\left(v_{\tilde{A}_{S}}^{2}+v_{\tilde{B}_{S}}^{2}-v_{\tilde{A}_{S}}^{2} v_{\tilde{B}_{S}}^{2}\right)^{\frac{1}{2}},\right.\right. \\
&\left.=\left(\left(1-v_{\tilde{B}_{S}}^{2}\right) \pi_{\tilde{A}_{S}}^{2}+\left(1-v_{\tilde{A}_{S}}^{2}\right) \pi_{\tilde{B}_{S}}^{2}-\pi_{\tilde{A}_{S}}^{2} \pi_{\tilde{B}_{S}}^{2}\right)^{\frac{1}{2}}\right\} \\
& \lambda * \tilde{A}_{S}=\left\{\left(1-\left(1-\mu_{\tilde{A}_{S}}^{2}\right)^{\lambda}\right)^{\frac{1}{2}}, v_{\tilde{A}_{S}}^{\lambda},\left(\left(1-\mu_{\tilde{A}_{S}}^{2}\right)^{\lambda}-\left(1-\mu_{\tilde{A}_{S}}^{2}-\pi_{\tilde{A}_{S}}^{2}\right)^{\lambda}\right)^{\frac{1}{2}}\right\}, \lambda>0(23) \\
& \tilde{A}_{S}^{\lambda}=\left\{\mu_{\tilde{A}_{S}}^{\lambda},\left(1-\left(1-v_{\tilde{A}_{S}}^{2}\right)^{\lambda}\right)^{\frac{1}{2}},\left(\left(1-v_{\tilde{A}_{S}}^{2}\right)^{\lambda}-\left(1-v_{\tilde{A}_{S}}^{2}-\pi_{\tilde{A}_{S}}^{2}\right)^{\lambda}\right)^{\frac{1}{2}}\right\}, \lambda>0
\end{aligned}
$$

In the final step, the spherical weighted arithmetic mean operator is calculated using Eq. (25).

$$
\begin{aligned}
\operatorname{SWAM}_{w}\left(\tilde{A}_{S 1}, ., \tilde{A}_{S n}\right)= & w_{1} \tilde{A}_{S 1}+\ldots+w_{n} \tilde{A}_{S n} \\
= & \left\{\left[1-\prod_{i=1}^{n}\left(1-\mu_{\tilde{A}_{S i}}^{2}\right)^{w_{i}}\right]^{\frac{1}{2}}, \prod_{i=1}^{n} v_{\tilde{A}_{S i}}^{w_{i}}\right. \\
& {\left.\left[\prod_{i=1}^{n}\left(1-\mu_{\tilde{A}_{S i}}^{2}\right)^{w_{i}}-\prod_{i=1}^{n}\left(1-\mu_{\tilde{A}_{S i}}^{2}-\pi_{\tilde{A}_{S i}}^{2}\right)^{w_{i}}\right]^{\frac{1}{2}}\right\}, }
\end{aligned}
$$

\section{DEMATEL}

The DEMATEL methodology aims to compute the weights of the different factors. The main advantage of this approach is that it develops an impact-relation map. This analysis 
facilitates making causal evaluations among the criteria. In the analysis process, first, experts' evaluations are collected. Subsequently, the direct relation matrix (A) is defined as in Eq. (26) using these evaluations (Jun et al. 2020).

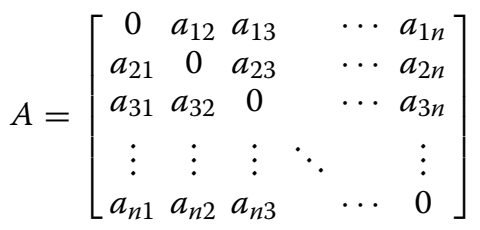

Subsequently, the normalization process is applied to this matrix with the help of Eqs. (27) and (28).

$$
\begin{aligned}
& B=\frac{A}{\max _{1 \leq i \leq n} \sum_{j=1}^{n} a_{i j}} \\
& 0 \leq b_{i j} \leq 1
\end{aligned}
$$

Next, total relation matrix $(C)$ is generated by considering Eq. (29). Within this context, the identity matrix is indicated by I (Qiu et al. 2020).

$$
C=B(I-B)^{-1}
$$

Furthermore, the sums of the rows and columns (D and E) are computed by considering Eqs. (30) and (31) (Zhang et al. 2020).

$$
\begin{aligned}
& D=\left[\sum_{j=1}^{n} e_{i j}\right]_{n x 1} \\
& E=\left[\sum_{i=1}^{n} e_{i j}\right]_{1 x n}
\end{aligned}
$$

Given this scope, the item weights are defined using the values of D $+\mathrm{E}$. Moreover, a causal relationship is defined with the help of the value of D-E. In addition, the threshold value $(\alpha)$ is used as in Eq. (32) to develop the impact-relation map (Yuan et al. 2020).

$$
\alpha=\frac{\sum_{i=1}^{n} \sum_{j=1}^{n}\left[e_{i j}\right]}{N}
$$

\section{Proposed model}

This study aims to evaluate the multidimensional due diligence of fintech-based financial alternatives for green energy investment projects. For this purpose, a two-stage model was generated. Figure 2 illustrates the details of this proposed model.

Figure 2 shows that the first phase includes the construction of the consensus results of multidimensional due diligence for fintech-based financing alternatives of green energy investment projects. For this purpose, the multidimensional factors of due diligence for fintech-based financing alternatives of green energy investment 


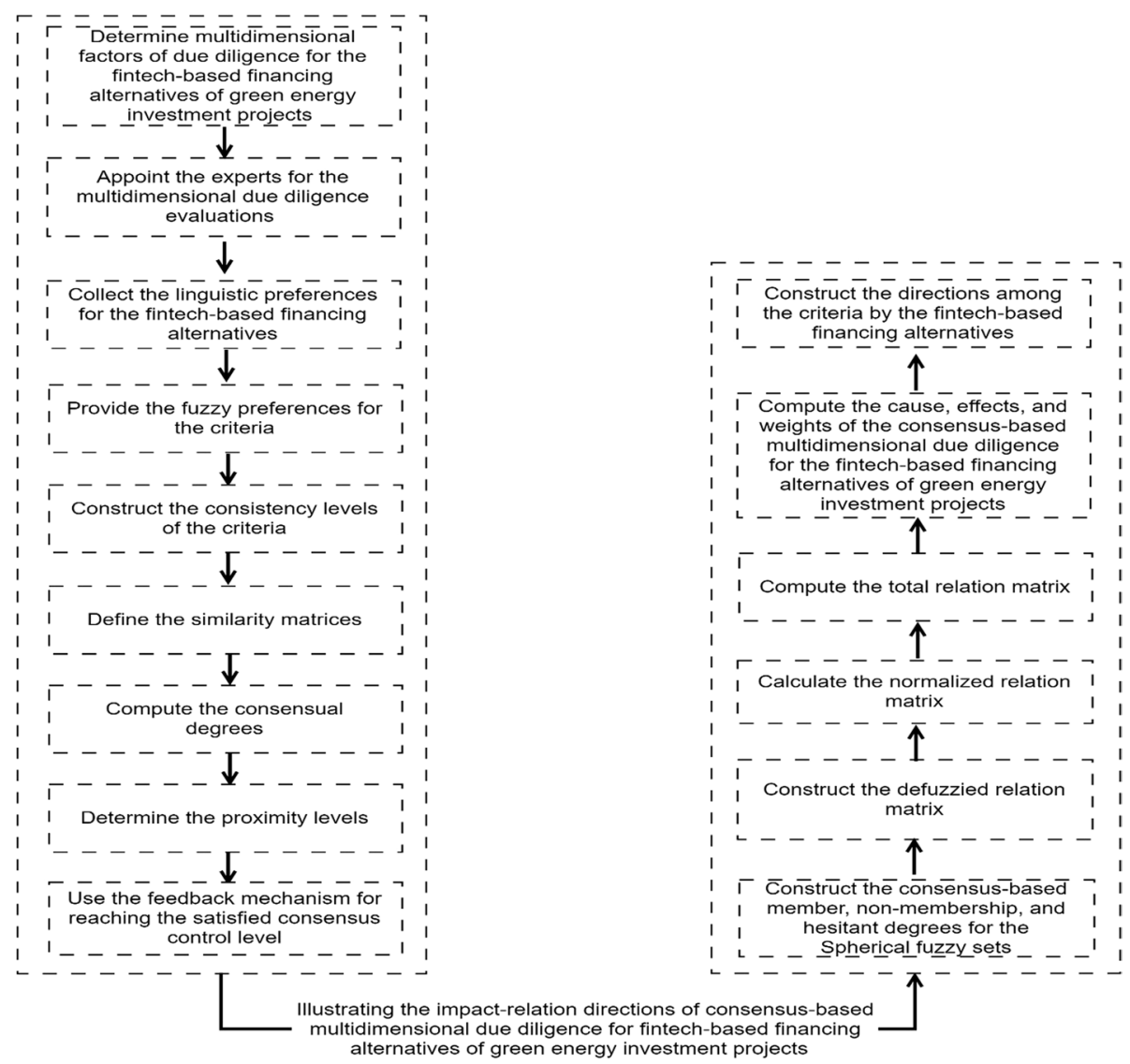

Fig. 2 Algorithm of the hybrid decision support system

projects are determined. In the next step, experts are appointed for the multidimensional due diligence evaluations. Next, the linguistic preferences are collected for fintech-based financing alternatives. Subsequently, fuzzy preferences are provided for the criteria. With the help of these values, the CL of the criteria is constructed, and the consensual degrees are computed. In the next step, the proximity levels are determined. Finally, the feedback mechanism is used to reach the satisfied CCL. Moreover, the second phase is related to illustrating the impact-relation directions of consensus-based multidimensional due diligence for fintech-based financing alternatives of green energy investment projects. Within this framework, the consensus-based membership, nonmembership, and hesitant degrees are generated for the spherical fuzzy sets. Subsequently, the defuzzied relation matrix is generated. In the following step, the normalized relation and total relation matrixes are developed. By considering these values, the weights of the consensus-based multidimensional due diligence for fintech-based financing alternatives of green energy investment projects are calculated. Similarly, the directions among the criteria by the fintech-based financing alternatives are also constructed with the help of these values.

This proposed model has some novelties. The most significant problem in the decision-making process is having different expert evaluations. This condition has 
a negative influence on the effectiveness of this process. For the consensus-based group decision-making methodology, the feedback mechanism can be applied to enable experts to reach a consensus (Liu and Pedrycz 2020). This situation provides the positive contribution of achieving more effective results (Zhang et al. 2019). In some previous models from the literature, the consensus methodology was not preferred (Dinçer et al. 2017; Ubay and Karakuş 2020a, b; Kalkavan et al. 2021). In these models, decision makers might provide different opinions about some factors. During the analysis process, the average of these factors was considered. However, if the consensus methodology was applied, the possibility exists that some of the experts might change their opinions (Zhang et al. 2019). In addition, considering spherical fuzzy sets in the analysis process provides some advantages. Membership, nonmembership, and hesitancy parameters can be considered with the help of these fuzzy sets (Kutlu Gündoğdu and Kahraman 2019). This situation has a positive influence on the effectiveness of the analysis results (Ashraf et al. 2019). Some different fuzzy sets were also preferred in the previous models in the literature. For instance, Wang and Kumbasar (2019), Li et al. (2020), and Qin et al. (2020) used interval type-2 fuzzy sets in their analyzes. The main advantage of these models is to more effectively handle the uncertainty in the decision-making process. However, the main superiority of spherical fuzzy sets relative to interval type- 2 fuzzy sets is to consider different parameters at the same time. This situation can be very helpful in reaching more appropriate results. Moreover, in this model, the criteria are defined by considering different balanced scorecard perspectives. Because of this situation, both financial and nonfinancial issues are considered in the evaluation process (Delen et al. 2020). Thus, an effective due diligence evaluation can be performed to examine fintech-based financial alternatives (Moraga et al. 2020). Finally, with the help of the DEMATEL methodology, the impact-relation map can be developed (Qiu et al. 2020). This situation is helpful for a causality analysis between the criteria (Yuan et al. 2020).

\section{Analysis}

This section includes explanations of the analysis results for two different phases.

\section{Constructing the consensus results of multidimensional due diligence for fintech-based financing alternatives of green energy investment projects (phase 1)}

In this phase, first, the multidimensional factors of due diligence for fintech-based financing alternatives of green energy investment projects are defined. For this purpose, the balanced scorecard perspectives are considered. Table 1 provides information on these criteria.

Table 1 shows that mainly four different criteria exist that influence the effectiveness of green energy investments. Financial returns (C1) aim to provide cost efficiency and increasing investment profits. Moreover, regarding customer expectations (C2), having the capacity to customize services and products of green energies is significant. Additionally, organizational competency (C3) includes the consistency of personnel and other organizational assets for the strategic success of projects. Finally, regarding market competency (C4), monitoring innovations and benchmarking renewable energy alternatives for sustainable investments are considered. These four criteria are used to evaluate 
Table 1 Balanced scorecard-based multidimensional due diligence for green energy investment projects

\begin{tabular}{lll}
\hline Balanced scorecard principles & Adopted criteria & Supported literature \\
\hline Finance & Financial returns (C1) & Fianto et al. (2018), Alzoubi (2018) \\
Customer & Customer expectations (C2) & Delen et al. (2020), Boratyńska (2019) \\
Internal Process & Organizational competency (C3) & Bu et al. (2021), Bertheau (2020) \\
Learning and growth & Market competency (C4) & Anshari et al. (2019), Gimpel et al. (2018) \\
\hline
\end{tabular}

Table 2 Details of experts

\begin{tabular}{lllll}
\hline Experts & Industry & Experience & Position & Education \\
\hline Expert 1 & Financial Institutions and & 22 years & Chairman & Business Engineering \\
& Asset Management & & & \\
Expert 2 & Energy & 25 years & Present & Industrial Engineering \\
Expert 3 & Construction & 18 years & Senior Vice Present & Civil Engineering \\
Expert 4 & Manufacturing & 16 years & Senior Vice Present & Industrial Engineering \\
\hline
\end{tabular}

the different fintech-based financing alternatives. In summary, the main hypothesis of the study is that financial returns, meeting customer expectations, organizational competency, and market competency positively affect the performance of green energy investment projects. However, green energy investment companies have a budget limitation, making it difficult to effectively focus on these four criteria at the same time. Therefore, in this study, these criteria are weighted. This analysis makes it possible to identify more significant factors to improve green energy investments. Therefore, strategies for more priority issues can be developed.

In this study, four different fintech-based financing alternatives are considered. First, a revenue sharing model can be considered for this purpose. This model reflects royalty payments based on sales performance (Yang et al. 2019a, b). In contrast, a peer-tobusiness debt model includes borrowing with a risk premium. The third fintech-based financing model is an equity sharing model that considers providing equity shares with shareholder rights (Alzoubi 2018). The rewarding model is the final approach in this regard. This model aims to provide projects' products and services at preorder prices (Harish et al. 2020). In this study's analysis process, the criteria, which are stated in Table 1, are evaluated for each fintech-based financing alternatives. To evaluate these factors, four different experts are appointed, and their details are provided in Table 2.

Table 2 shows that the experts have sufficient knowledge to evaluate green energy investment factors. The linguistic preferences for fintech-based financing alternatives are collected from these experts. For this purpose, the linguistic scales and fuzzy preference numbers, as provided in Table 3 , are used.

Experts' evaluations regarding fintech-based financing alternatives are indicated in Table 4.

Next, consensus-based group decision-making analyses are performed. In this framework, the details of the calculation of the revenue sharing model are presented below. Additionally, only the analysis results of the other fintech-based financing 
Table 3 Linguistic scales and fuzzy preference numbers

\begin{tabular}{lll}
\hline Linguistic scales & Preference numbers & $\begin{array}{l}\text { Fuzzy } \\
\text { preferences }\end{array}$ \\
\hline No influence $(n)$ & 0 & 0 \\
Weak influence $(w)$ & 1 & 0.10 \\
Somewhat influence $(s)$ & 2 & 0.30 \\
Medium influence $(m)$ & 3 & 0.50 \\
High influence $(\mathrm{h})$ & 4 & 0.70 \\
Very high influence $(\mathrm{vh})$ & 5 & 0.90 \\
Extremely influence $(\mathrm{e})$ & 6 & 1 \\
\hline
\end{tabular}

alternatives are shared. Table 5 provides information on the fuzzy preference relations for the revenue sharing model.

Additionally, the corresponding fuzzy preference relations for the revenue sharing model are demonstrated in Table 6.

In the following step, the $\mathrm{CL}$ of the criteria are calculated. Table 7 indicates the details of decision-makers' CL for the revenue sharing model.

The GCL for the revenue sharing model is 0.87 . The same procedure is applied for the other models, and the global consistency levels are computed as 0.90 for the peerto-business debt model, 0.88 for the equity sharing model, and 0.91 for the rewarding model. Next, the similarity matrixes are calculated. Table 8 explains the details of the similarity matrixes with respect to the revenue sharing model.

Furthermore, the collective similarity matrix for the revenue sharing model is indicated in Table 9.

In the following step, the consensual degrees are calculated. The global consensus degree (CR) is computed as 0.83 for the revenue sharing model. Similarly, the global consensus degree is also computed for the peer-to-business debt model as 0.93; for the equity sharing model as 0.89 ; and for the rewarding model as 0.90 . Table 10 provides information on the consensual fuzzy preference degrees for the revenue sharing model.

Additionally, the collective fuzzy preference relations for the revenue sharing model are detailed in Table 11.

Furthermore, the proximity levels are identified. Table 12 indicates the proximity levels for the revenue sharing model.

The CCL value for the revenue sharing model is 0.84 . A similar procedure is also properly applied for the remaining models. The CCL values are calculated as 0.88 for the peer-to-business debt model, 0.80 for the equity sharing model, and 0.90 for the rewarding model. Subsequently, the feedback mechanism is implemented to achieve a satisfied CCL. Consensus-based group fuzzy preferences are controlled by considering the value of 0.85 as a threshold for the CCL. Once the CCL is lower than the value of the threshold, the following round consensus reaching model is repeated. Therefore, the revised consensus processes continue until the value reaches 0.85 . Accordingly, the feedback mechanism is applied. The peer-to-business debt and rewarding models exceed the threshold value with the values of 0.88 and 0.90 , and the fuzzy preference relations for the peer-to-business debt and rewarding models can be 
Table 4 Linguistic evaluations for fintech-based financing alternatives

\begin{tabular}{|c|c|c|c|c|c|c|c|c|c|}
\hline \multicolumn{5}{|c|}{ Decision maker 1} & \multicolumn{5}{|c|}{ Decision maker 2} \\
\hline DM1 & $\mathrm{C} 1$ & $\mathrm{C} 2$ & C3 & $\mathrm{C} 4$ & DM2 & C1 & $\mathrm{C} 2$ & $\mathrm{C} 3$ & C4 \\
\hline \multicolumn{10}{|c|}{ Revenue sharing model } \\
\hline $\mathrm{C} 1$ & - & $\mathrm{H}$ & M & M & $\mathrm{C} 1$ & - & $\mathrm{VH}$ & $\mathrm{S}$ & $\mathrm{H}$ \\
\hline C2 & $\mathrm{H}$ & - & VH & M & $\mathrm{C} 2$ & $\mathrm{VH}$ & - & $\mathrm{H}$ & M \\
\hline C3 & $\mathrm{H}$ & $\mathrm{VH}$ & - & $\mathrm{VH}$ & $\mathrm{C} 3$ & $\mathrm{H}$ & $\mathrm{H}$ & - & $\mathrm{H}$ \\
\hline C4 & M & S & M & - & C4 & $\mathrm{H}$ & M & $\mathrm{VH}$ & - \\
\hline \multicolumn{5}{|c|}{ Decision maker 3} & \multicolumn{5}{|c|}{ Decision maker 4} \\
\hline DM3 & C1 & $\mathrm{C} 2$ & C3 & C4 & DM4 & C1 & $\mathrm{C} 2$ & $\mathrm{C} 3$ & C4 \\
\hline \multicolumn{10}{|c|}{ Revenue sharing model } \\
\hline C1 & - & S & M & $S$ & $\mathrm{C} 1$ & - & $\mathrm{H}$ & M & $S$ \\
\hline C2 & $\mathrm{VH}$ & - & M & M & $\mathrm{C} 2$ & M & - & $\mathrm{H}$ & M \\
\hline C3 & M & $\mathrm{VH}$ & - & $\mathrm{H}$ & $\mathrm{C} 3$ & M & M & - & $\mathrm{H}$ \\
\hline C4 & M & S & $\mathrm{H}$ & - & C4 & S & $S$ & $\mathrm{H}$ & - \\
\hline \multicolumn{5}{|c|}{ Decision maker 1} & \multicolumn{5}{|c|}{ Decision maker 2} \\
\hline DM1 & C1 & $\mathrm{C} 2$ & C3 & C4 & DM2 & C1 & $\mathrm{C} 2$ & $\mathrm{C} 3$ & C4 \\
\hline \multicolumn{10}{|c|}{ Business debt model } \\
\hline $\mathrm{C} 1$ & - & $\mathrm{H}$ & $\mathrm{H}$ & $\mathrm{H}$ & $\mathrm{C} 1$ & - & M & S & M \\
\hline C2 & M & - & VH & M & $\mathrm{C} 2$ & $\mathrm{H}$ & - & $\mathrm{H}$ & M \\
\hline C3 & $\mathrm{H}$ & M & - & $\mathrm{H}$ & $\mathrm{C} 3$ & $\mathrm{H}$ & $\mathrm{H}$ & - & $\mathrm{H}$ \\
\hline C4 & $\mathrm{H}$ & $S$ & M & - & C4 & $\mathrm{H}$ & M & $\mathrm{H}$ & - \\
\hline \multicolumn{5}{|c|}{ Decision maker 3} & \multicolumn{5}{|c|}{ Decision maker 4} \\
\hline DM3 & $\mathrm{C} 1$ & $\mathrm{C} 2$ & C3 & $\mathrm{C4}$ & DM4 & C1 & $\mathrm{C} 2$ & $\mathrm{C} 3$ & $\mathrm{C4}$ \\
\hline \multicolumn{10}{|c|}{ Business debt model } \\
\hline C1 & - & $\mathrm{H}$ & M & M & $\mathrm{C} 1$ & - & M & M & M \\
\hline C2 & $\mathrm{VH}$ & - & M & M & $\mathrm{C} 2$ & $\mathrm{H}$ & - & $\mathrm{H}$ & M \\
\hline C3 & $\mathrm{H}$ & $\mathrm{H}$ & - & M & $\mathrm{C} 3$ & M & M & - & $\mathrm{H}$ \\
\hline C4 & M & S & $\mathrm{H}$ & - & $\mathrm{C} 4$ & $\mathrm{H}$ & $\mathrm{VH}$ & $\mathrm{H}$ & - \\
\hline \multicolumn{5}{|c|}{ Decision maker 1} & \multicolumn{5}{|c|}{ Decision maker 2} \\
\hline DM1 & C1 & $\mathrm{C} 2$ & C3 & $\mathrm{C} 4$ & DM2 & C1 & $\mathrm{C} 2$ & $\mathrm{C} 3$ & $\mathrm{C4}$ \\
\hline \multicolumn{10}{|c|}{ Equity sharing model } \\
\hline C1 & - & M & $\mathrm{H}$ & $\mathrm{H}$ & $\mathrm{C} 1$ & - & $\mathrm{VH}$ & $\mathrm{H}$ & M \\
\hline C2 & M & - & VH & $\mathrm{VH}$ & $\mathrm{C} 2$ & $\mathrm{H}$ & - & $\mathrm{H}$ & M \\
\hline C3 & $\mathrm{VH}$ & M & - & M & $\mathrm{C} 3$ & $\mathrm{VH}$ & M & - & $S$ \\
\hline C4 & $\mathrm{VH}$ & S & $\mathrm{H}$ & - & C4 & M & M & $\mathrm{H}$ & - \\
\hline \multicolumn{5}{|c|}{ Decision maker 3} & \multicolumn{5}{|c|}{ Decision maker 4} \\
\hline DM3 & $\mathrm{C} 1$ & $\mathrm{C} 2$ & $\mathrm{C} 3$ & $\mathrm{C} 4$ & DM4 & $\mathrm{C} 1$ & $\mathrm{C} 2$ & $\mathrm{C} 3$ & $\mathrm{C} 4$ \\
\hline \multicolumn{10}{|c|}{ Equity sharing model } \\
\hline $\mathrm{Cl}$ & - & $\mathrm{H}$ & M & M & $\mathrm{C} 1$ & - & $\mathrm{H}$ & S & $\mathrm{VH}$ \\
\hline C2 & $\mathrm{H}$ & - & $\mathrm{H}$ & M & $\mathrm{C} 2$ & $\mathrm{VH}$ & - & $S$ & $\mathrm{H}$ \\
\hline C3 & $M$ & $\mathrm{H}$ & - & $\mathrm{VH}$ & C3 & $\mathrm{H}$ & $M$ & - & $\mathrm{H}$ \\
\hline C4 & $\mathrm{H}$ & $S$ & $\mathrm{H}$ & - & C4 & $\mathrm{H}$ & $\mathrm{H}$ & $M$ & - \\
\hline
\end{tabular}


Table 4 (continued)

\begin{tabular}{|c|c|c|c|c|c|c|c|c|c|}
\hline \multicolumn{5}{|c|}{ Decision maker 1} & \multicolumn{5}{|c|}{ Decision maker 2} \\
\hline DM1 & $\mathrm{C} 1$ & C2 & $\mathrm{C} 3$ & $\mathrm{C} 4$ & DM2 & C1 & $\mathrm{C} 2$ & $\mathrm{C} 3$ & $\mathrm{C4}$ \\
\hline \multicolumn{10}{|c|}{ Rewarding model } \\
\hline C1 & - & $\mathrm{H}$ & M & $\mathrm{H}$ & C1 & - & $\mathrm{H}$ & M & M \\
\hline C2 & $\mathrm{VH}$ & - & $\mathrm{VH}$ & $\mathrm{H}$ & C2 & $\mathrm{H}$ & - & $\mathrm{H}$ & $\mathrm{VH}$ \\
\hline C3 & M & M & - & $\mathrm{H}$ & C3 & M & $\mathrm{H}$ & - & $\mathrm{H}$ \\
\hline C4 & $\mathrm{H}$ & $\mathrm{H}$ & M & - & C4 & $\mathrm{H}$ & M & $\mathrm{H}$ & - \\
\hline \multicolumn{5}{|c|}{ Decision maker 3} & \multicolumn{5}{|c|}{ Decision maker 4} \\
\hline DM3 & $\mathrm{C} 1$ & C2 & $\mathrm{C} 3$ & $\mathrm{C} 4$ & DM4 & C1 & $\mathrm{C} 2$ & $\mathrm{C} 3$ & C4 \\
\hline \multicolumn{10}{|c|}{ Rewarding model } \\
\hline $\mathrm{C} 1$ & - & $\mathrm{H}$ & M & M & C1 & - & $\mathrm{H}$ & M & $\mathrm{H}$ \\
\hline C2 & $\mathrm{H}$ & - & M & M & C2 & VH & - & $\mathrm{H}$ & $\mathrm{H}$ \\
\hline C3 & M & $\mathrm{H}$ & - & M & C3 & $\mathrm{H}$ & $\mathrm{H}$ & - & $\mathrm{H}$ \\
\hline C4 & $\mathrm{H}$ & $\mathrm{H}$ & $\mathrm{H}$ & - & C4 & $M$ & $\mathrm{H}$ & $\mathrm{H}$ & - \\
\hline
\end{tabular}

Table 5 Fuzzy preference relations for revenue sharing model

\begin{tabular}{|c|c|c|c|c|c|c|c|c|c|}
\hline \multicolumn{5}{|c|}{ Decision maker 1} & \multicolumn{5}{|c|}{ Decision maker 2} \\
\hline$P^{1}$ & $\mathrm{C} 1$ & $\mathrm{C2}$ & $\mathrm{C} 3$ & $\mathrm{C} 4$ & $\overline{P^{2}}$ & C1 & $\mathrm{C} 2$ & $\mathrm{C} 3$ & $\mathrm{C} 4$ \\
\hline C1 & - & 0.70 & 0.50 & 0.50 & $\mathrm{C} 1$ & - & 0.90 & 0.30 & 0.70 \\
\hline$C 2$ & 0.70 & - & 0.90 & 0.50 & $\mathrm{C} 2$ & 0.90 & - & 0.70 & 0.50 \\
\hline C3 & 0.70 & 0.90 & - & 0.90 & C3 & 0.70 & 0.70 & - & 0.70 \\
\hline C4 & 0.50 & 0.30 & 0.50 & - & $\mathrm{C} 4$ & 0.70 & 0.50 & 0.90 & - \\
\hline \multicolumn{5}{|c|}{ Decision maker 3} & \multicolumn{5}{|c|}{ Decision maker 4} \\
\hline$P^{3}$ & C1 & $\mathrm{C} 2$ & $\mathrm{C} 3$ & $\mathrm{C} 4$ & $\mathrm{P}^{4}$ & $\mathrm{C} 1$ & $\mathrm{C} 2$ & C3 & $\mathrm{C} 4$ \\
\hline C1 & - & 0.30 & 0.50 & 0.30 & $\mathrm{C} 1$ & - & 0.70 & 0.50 & 0.30 \\
\hline C2 & 0.90 & - & 0.50 & 0.50 & $\mathrm{C} 2$ & 0.50 & - & 0.70 & 0.50 \\
\hline C3 & 0.50 & 0.90 & - & 0.70 & C3 & 0.50 & 0.50 & - & 0.70 \\
\hline C4 & 0.50 & 0.30 & 0.70 & - & C4 & 0.30 & 0.30 & 0.70 & - \\
\hline
\end{tabular}

Table 6 Corresponding fuzzy preference relations for revenue sharing model

\begin{tabular}{|c|c|c|c|c|c|c|c|c|c|}
\hline \multicolumn{5}{|c|}{ Decision maker 1} & \multicolumn{5}{|c|}{ Decision maker 2} \\
\hline $\mathrm{CP}^{1}$ & C1 & $\mathrm{C} 2$ & C3 & $\mathrm{C4}$ & $\overline{\mathrm{CP}^{2}}$ & C1 & $\mathrm{C2}$ & C3 & C4 \\
\hline C1 & - & 0.47 & 0.53 & 0.67 & $\mathrm{C} 1$ & - & 0.47 & 0.73 & 0.47 \\
\hline C2 & 0.67 & - & 0.47 & 0.73 & $\mathrm{C} 2$ & 0.67 & - & 0.57 & 0.63 \\
\hline C3 & 0.73 & 0.67 & - & 0.67 & $\mathrm{C} 3$ & 0.63 & 0.67 & - & 0.67 \\
\hline C4 & 0.47 & 0.53 & 0.47 & - & $\mathrm{C} 4$ & 0.77 & 0.73 & 0.47 & - \\
\hline \multicolumn{5}{|c|}{ Decision maker 3} & \multicolumn{5}{|c|}{ Decision maker 4} \\
\hline $\mathrm{CP}^{3}$ & $\mathrm{C} 1$ & $\mathrm{C} 2$ & $\mathrm{C} 3$ & $\mathrm{C} 4$ & $\overline{\mathrm{CP}^{4}}$ & $\mathrm{C} 1$ & $\mathrm{C} 2$ & C3 & $\mathrm{C} 4$ \\
\hline C1 & - & 0.50 & 0.27 & 0.43 & C1 & - & 0.37 & 0.63 & 0.63 \\
\hline C2 & 0.50 & - & 0.73 & 0.57 & $\mathrm{C} 2$ & 0.57 & - & 0.53 & 0.53 \\
\hline C3 & 0.87 & 0.33 & - & 0.60 & C3 & 0.43 & 0.53 & - & 0.47 \\
\hline C4 & 0.63 & 0.57 & 0.40 & - & C4 & 0.43 & 0.53 & 0.47 & - \\
\hline
\end{tabular}


Table 7 Decision-makers' consistency levels for revenue sharing model

\begin{tabular}{|c|c|c|c|c|c|c|c|c|c|}
\hline \multicolumn{5}{|c|}{ Decision maker $1\left(\mathrm{CL}^{1}: 0.89\right)$} & \multicolumn{5}{|c|}{ Decision maker $2\left(\mathrm{CL}^{2}: 0.86\right)$} \\
\hline $\mathrm{CL}^{1}$ & $\mathrm{C} 1$ & $\mathrm{C} 2$ & $\mathrm{C} 3$ & $\mathrm{C} 4$ & $\mathrm{CL}^{2}$ & $\mathrm{C} 1$ & $\mathrm{C} 2$ & $\mathrm{C} 3$ & $\mathrm{C} 4$ \\
\hline C1 & - & 0.84 & 0.98 & 0.89 & C1 & - & 0.71 & 0.71 & 0.84 \\
\hline C2 & 0.98 & - & 0.71 & 0.84 & $\mathrm{C} 2$ & 0.84 & - & 0.91 & 0.91 \\
\hline C3 & 0.98 & 0.84 & - & 0.84 & C3 & 0.96 & 0.98 & - & 0.98 \\
\hline C4 & 0.98 & 0.84 & 0.98 & - & C4 & 0.96 & 0.84 & 0.71 & - \\
\hline \multicolumn{5}{|c|}{ Decision maker $3\left(\mathrm{CL}^{3}: 0.83\right)$} & \multicolumn{5}{|c|}{ Decision maker $4\left(\mathrm{CL}^{4}: 0.89\right)$} \\
\hline $\mathrm{CL}^{3}$ & $\mathrm{C} 1$ & $\mathrm{C} 2$ & $\mathrm{C} 3$ & $\mathrm{C} 4$ & $\mathrm{CL}^{4}$ & $\mathrm{C} 1$ & $\mathrm{C} 2$ & C3 & $\mathrm{C} 4$ \\
\hline C1 & - & 0.87 & 0.84 & 0.91 & $\mathrm{C} 1$ & - & 0.78 & 0.91 & 0.78 \\
\hline C2 & 0.73 & - & 0.84 & 0.96 & $C 2$ & 0.96 & - & 0.89 & 0.98 \\
\hline C3 & 0.76 & 0.62 & - & 0.93 & C3 & 0.96 & 0.98 & - & 0.84 \\
\hline C4 & 0.91 & 0.82 & 0.80 & - & C4 & 0.91 & 0.84 & 0.84 & - \\
\hline
\end{tabular}

Table 8 Similarity matrixes for revenue sharing model

\begin{tabular}{|c|c|c|c|c|c|c|c|c|c|}
\hline \multicolumn{5}{|c|}{ DM1-DM3 } & \multicolumn{5}{|c|}{ DM1-DM4 } \\
\hline$S M^{13}$ & $\mathrm{C} 1$ & $\mathrm{C} 2$ & C3 & $\mathrm{C} 4$ & $S M^{14}$ & $\mathrm{C} 1$ & $\mathrm{C} 2$ & C3 & C4 \\
\hline C1 & & 0.60 & 1.00 & 0.80 & $\mathrm{C} 1$ & & 1.00 & 1.00 & 0.80 \\
\hline C2 & 0.80 & & 0.60 & 1.00 & $C 2$ & 0.8 & & 0.80 & 1.00 \\
\hline C3 & 0.80 & 1.00 & & 0.80 & C3 & 0.80 & 0.60 & & 0.80 \\
\hline C4 & 1.00 & 1.00 & 0.80 & & C4 & 0.8 & 1.00 & 0.80 & \\
\hline \multicolumn{5}{|c|}{ DM2-DM3 } & \multicolumn{5}{|c|}{ DM2-DM4 } \\
\hline$S M^{23}$ & $\mathrm{C} 1$ & $\mathrm{C} 2$ & C3 & $\mathrm{C} 4$ & $S^{24}$ & $\mathrm{C} 1$ & $\mathrm{C} 2$ & $\mathrm{C} 3$ & $\mathrm{C} 4$ \\
\hline C1 & & 0.40 & 0.80 & 0.60 & $\mathrm{C} 1$ & & 0.80 & 0.80 & 0.60 \\
\hline C2 & 1.00 & & 0.80 & 1.00 & $C 2$ & 0.60 & & 1.00 & 1.00 \\
\hline C3 & 0.80 & 0.80 & & 1.00 & $\mathrm{C} 3$ & 0.80 & 0.80 & & 1.00 \\
\hline C4 & 0.80 & 0.80 & 0.80 & & C4 & 0.60 & 0.80 & 0.80 & \\
\hline
\end{tabular}

Table 9 Collective similarity matrix for revenue sharing model

\begin{tabular}{lllll}
\hline SM & C1 & C2 & C3 & C4 \\
\hline C1 & & 0.70 & 0.90 & 0.70 \\
C2 & 0.80 & & 0.80 & 1.00 \\
C3 & 0.80 & 0.80 & & 0.90 \\
C4 & 0.80 & 0.90 & 0.80 & \\
\hline
\end{tabular}

considered consensus-based preferences because of the satisfied CCLs. The consensus-based fuzzy preference relations are presented for the peer-to-business model in Table 13.

These values regarding the rewarding models are represented in Table 14.

However, the CCL values, at 0.84 and 0.80 , respectively, illustrate that revenue and equity sharing models do not satisfy the consensus control level and need for the second-round process for reaching the consensus level. The evaluation process of revenue 
Table 10 Consensual fuzzy preference degrees for revenue sharing model

\begin{tabular}{|c|c|c|c|c|c|c|c|c|c|}
\hline \multicolumn{5}{|c|}{ Decision maker 1} & \multicolumn{5}{|c|}{ Decision maker 2} \\
\hline$\overline{Z^{1}}$ & $\mathrm{C} 1$ & $\mathrm{C} 2$ & $\mathrm{C} 3$ & $\mathrm{C} 4$ & $\mathrm{Z}^{2}$ & C1 & $\mathrm{C} 2$ & $\mathrm{C} 3$ & $\mathrm{C} 4$ \\
\hline C1 & & 0.81 & 0.94 & 0.82 & $\mathrm{C} 1$ & & 0.68 & 0.78 & 0.71 \\
\hline$C 2$ & 0.84 & & 0.73 & 0.96 & $C 2$ & 0.81 & & 0.88 & 0.98 \\
\hline C3 & 0.89 & 0.81 & & 0.81 & C3 & 0.89 & 0.84 & & 0.94 \\
\hline C4 & 0.89 & 0.91 & 0.79 & & C4 & 0.79 & 0.81 & 0.73 & \\
\hline \multicolumn{5}{|c|}{ Decision maker 3} & \multicolumn{5}{|c|}{ Decision maker 4} \\
\hline$Z^{3}$ & $\mathrm{C} 1$ & $\mathrm{C} 2$ & $\mathrm{C} 3$ & $\mathrm{C} 4$ & $\overline{z^{4}}$ & $\mathrm{C} 1$ & $\mathrm{C} 2$ & C3 & C4 \\
\hline $\mathrm{C} 1$ & & 0.62 & 0.91 & 0.83 & $\mathrm{C} 1$ & & 0.79 & 0.93 & 0.79 \\
\hline $\mathrm{C} 2$ & 0.78 & & 0.76 & 0.99 & $\mathrm{C} 2$ & 0.74 & & 0.87 & 0.99 \\
\hline C3 & 0.84 & 0.76 & & 0.93 & C3 & 0.89 & 0.74 & & 0.91 \\
\hline C4 & 0.88 & 0.91 & 0.85 & & $\mathrm{C} 4$ & 0.78 & 0.91 & 0.86 & \\
\hline
\end{tabular}

Table 11 Collective fuzzy preference relations for revenue sharing model

\begin{tabular}{lllll}
\hline $\mathbf{P}$ & $\mathbf{C 1}$ & $\mathbf{C 2}$ & $\mathbf{C 3}$ & $\mathbf{C 4}$ \\
\hline $\mathrm{C} 1$ & & 0.75 & 0.90 & 0.80 \\
$\mathrm{C} 2$ & 0.81 & & 0.79 & 0.97 \\
$\mathrm{C} 3$ & 0.88 & 0.80 & & 0.87 \\
$\mathrm{C} 4$ & 0.85 & 0.89 & 0.80 & \\
\hline
\end{tabular}

Table 12 Proximity levels for revenue sharing model

\begin{tabular}{|c|c|c|c|c|c|c|c|c|c|}
\hline \multicolumn{5}{|c|}{ Decision maker $1\left(\operatorname{Pr}^{1}: 0.75\right)$} & \multicolumn{5}{|c|}{ Decision maker $2\left(\operatorname{Pr}^{2}: 0.78\right)$} \\
\hline $\mathrm{PP}^{1}$ & C1 & C2 & C3 & C4 & $\overline{\mathrm{PP}^{2}}$ & C1 & C2 & C3 & C4 \\
\hline C1 & & 0.95 & 0.60 & 0.70 & $\mathrm{C} 1$ & & 0.85 & 0.40 & 0.90 \\
\hline $\mathrm{C2}$ & 0.89 & & 0.89 & 0.53 & $\mathrm{C} 2$ & 0.91 & & 0.91 & 0.53 \\
\hline $\mathrm{C} 3$ & 0.82 & 0.90 & & 0.97 & $\mathrm{C} 3$ & 0.82 & 0.90 & & 0.83 \\
\hline C4 & 0.65 & 0.41 & 0.70 & & C4 & 0.85 & 0.61 & 0.90 & \\
\hline \multicolumn{5}{|c|}{ Decision maker $3\left(\mathrm{Pr}^{3}: 0.68\right)$} & \multicolumn{5}{|c|}{ Decision maker $4\left(\mathrm{Pr}^{4}: 0.67\right)$} \\
\hline $\mathrm{PP}^{3}$ & C1 & $\mathrm{C} 2$ & C3 & C4 & $\mathrm{PP}^{4}$ & C1 & $\mathrm{C} 2$ & $\mathrm{C3}$ & C4 \\
\hline $\mathrm{C} 1$ & & 0.55 & 0.60 & 0.50 & $\mathrm{C} 1$ & & 0.95 & 0.60 & 0.50 \\
\hline C2 & 0.91 & & 0.71 & 0.53 & $\mathrm{C} 2$ & 0.69 & & 0.91 & 0.53 \\
\hline C3 & 0.62 & 0.90 & & 0.83 & C3 & 0.62 & 0.70 & & 0.83 \\
\hline $\mathrm{C} 4$ & 0.65 & 0.41 & 0.90 & & C4 & 0.45 & 0.41 & 0.90 & \\
\hline
\end{tabular}

and equity sharing models is repeated for the second round. The second-round fuzzy preferences are provided in Table 15 for revenue sharing models.

The CCL value for the second-round fuzzy preferences of the revenue sharing model is 0.85 , which satisfies the consensus-based results. Thus, the next round evaluation process will not be applied, and the results are considered as consensus-based fuzzy preference relations for the revenue sharing model. Table 16 explains the details of the second-round fuzzy preferences for the equity sharing model. 
Table 13 Consensus-based fuzzy preference relations for peer-to-business debt model

\begin{tabular}{|c|c|c|c|c|c|c|c|c|c|}
\hline \multicolumn{5}{|c|}{ Decision maker 1} & \multicolumn{5}{|c|}{ Decision maker 2} \\
\hline$P^{1}$ & $\mathrm{C} 1$ & $\mathrm{C} 2$ & $\mathrm{C} 3$ & $\mathrm{C} 4$ & $\overline{P^{2}}$ & C1 & $\mathrm{C} 2$ & C3 & $\mathrm{C} 4$ \\
\hline $\mathrm{C} 1$ & - & 0.70 & 0.70 & 0.70 & $\mathrm{C} 1$ & - & 0.50 & 0.30 & 0.50 \\
\hline $\mathrm{C} 2$ & 0.50 & - & 0.90 & 0.50 & $\mathrm{C} 2$ & 0.70 & - & 0.70 & 0.50 \\
\hline C3 & 0.70 & 0.50 & - & 0.70 & C3 & 0.70 & 0.70 & - & 0.70 \\
\hline C4 & 0.70 & 0.30 & 0.50 & - & $\mathrm{C} 4$ & 0.70 & 0.50 & 0.70 & - \\
\hline \multicolumn{5}{|c|}{ Decision maker 3} & \multicolumn{5}{|c|}{ Decision maker 4} \\
\hline $\mathrm{P}^{3}$ & $\mathrm{C} 1$ & $\mathrm{C} 2$ & $\mathrm{C} 3$ & $\mathrm{C} 4$ & $\overline{\mathrm{P}^{4}}$ & C1 & $\mathrm{C2}$ & C3 & C4 \\
\hline C1 & - & 0.70 & 0.50 & 0.50 & $\mathrm{C} 1$ & - & 0.50 & 0.50 & 0.50 \\
\hline $\mathrm{C} 2$ & 0.90 & - & 0.50 & 0.50 & $\mathrm{C} 2$ & 0.70 & - & 0.70 & 0.50 \\
\hline C3 & 0.70 & 0.70 & - & 0.50 & C3 & 0.50 & 0.50 & - & 0.70 \\
\hline C4 & 0.50 & 0.30 & 0.70 & - & C4 & 0.70 & 0.90 & 0.70 & - \\
\hline
\end{tabular}

Table 14 Consensus-based fuzzy preference relations for rewarding model

\begin{tabular}{|c|c|c|c|c|c|c|c|c|c|}
\hline \multicolumn{5}{|c|}{ Decision maker 1} & \multicolumn{5}{|c|}{ Decision maker 2} \\
\hline$\overline{P^{1}}$ & C1 & $\mathrm{C} 2$ & $\mathrm{C} 3$ & $\mathrm{C} 4$ & $\mathrm{P}^{2}$ & $\mathrm{C} 1$ & $\mathrm{C} 2$ & C3 & $\mathrm{C} 4$ \\
\hline C1 & - & 0.70 & 0.50 & 0.70 & $\mathrm{C} 1$ & - & 0.70 & 0.50 & 0.50 \\
\hline $\mathrm{C} 2$ & 0.90 & - & 0.90 & 0.70 & $C 2$ & 0.70 & - & 0.70 & 0.90 \\
\hline C3 & 0.50 & 0.50 & - & 0.70 & C3 & 0.50 & 0.70 & - & 0.70 \\
\hline C4 & 0.70 & 0.70 & 0.50 & - & $\mathrm{C} 4$ & 0.70 & 0.50 & 0.70 & - \\
\hline \multicolumn{5}{|c|}{ Decision maker 3} & \multicolumn{5}{|c|}{ Decision maker 4} \\
\hline $\mathrm{P}^{3}$ & $\mathrm{C} 1$ & $\mathrm{C} 2$ & $\mathrm{C} 3$ & $\mathrm{C} 4$ & $\overline{\mathrm{P}^{4}}$ & $\mathrm{C1}$ & $\mathrm{C} 2$ & C3 & $\mathrm{C} 4$ \\
\hline $\mathrm{C} 1$ & - & 0.70 & 0.50 & 0.50 & $\mathrm{Cl}$ & - & 0.70 & 0.50 & 0.70 \\
\hline C2 & 0.70 & - & 0.50 & 0.50 & $C 2$ & 0.90 & - & 0.70 & 0.70 \\
\hline $\mathrm{C} 3$ & 0.50 & 0.70 & - & 0.50 & C3 & 0.70 & 0.70 & - & 0.70 \\
\hline C4 & 0.70 & 0.70 & 0.70 & - & $\mathrm{C} 4$ & 0.50 & 0.70 & 0.70 & - \\
\hline
\end{tabular}

Table 15 Second-round fuzzy preferences for revenue sharing model

\begin{tabular}{|c|c|c|c|c|c|c|c|c|c|}
\hline \multicolumn{5}{|c|}{ Decision maker 1} & \multicolumn{5}{|c|}{ Decision maker 2} \\
\hline$P^{1}$ & $\mathrm{C} 1$ & $\mathrm{C} 2$ & $\mathrm{C} 3$ & $\mathrm{C} 4$ & $\mathrm{P}^{2}$ & C1 & $\mathrm{C} 2$ & $\mathrm{C} 3$ & C4 \\
\hline C1 & - & 0.70 & 0.50 & 0.50 & $\mathrm{C} 1$ & - & 0.90 & 0.30 & 0.70 \\
\hline C2 & 0.70 & - & 0.90 & 0.91 & $C 2$ & 0.90 & - & 0.70 & 0.50 \\
\hline C3 & 0.70 & 0.90 & - & 0.90 & C3 & 0.70 & 0.70 & - & 0.70 \\
\hline C4 & 0.76 & 0.80 & 0.50 & - & C4 & 0.70 & 0.85 & 0.90 & - \\
\hline \multicolumn{5}{|c|}{ Decision maker 3} & \multicolumn{5}{|c|}{ Decision maker 4} \\
\hline $\mathrm{P}^{3}$ & $\mathrm{C} 1$ & $\mathrm{C} 2$ & $\mathrm{C} 3$ & $\mathrm{C} 4$ & $\mathrm{P}^{4}$ & $\mathrm{C} 1$ & $\mathrm{C} 2$ & $\mathrm{C} 3$ & $\mathrm{C} 4$ \\
\hline C1 & - & 0.69 & 0.74 & 0.70 & $\mathrm{C} 1$ & - & 0.70 & 0.84 & 0.75 \\
\hline C2 & 0.90 & - & 0.77 & 0.87 & $C 2$ & 0.50 & - & 0.70 & 0.50 \\
\hline C3 & 0.50 & 0.90 & - & 0.70 & C3 & 0.50 & 0.50 & - & 0.70 \\
\hline C4 & 0.80 & 0.81 & 0.70 & - & C4 & 0.75 & 0.80 & 0.70 & - \\
\hline
\end{tabular}


Table 16 Second-round fuzzy preferences for equity sharing model

\begin{tabular}{|c|c|c|c|c|c|c|c|c|c|}
\hline \multicolumn{5}{|c|}{ Decision maker 1} & \multicolumn{5}{|c|}{ Decision maker 2} \\
\hline $\mathbf{P}^{1}$ & C1 & $\mathrm{C} 2$ & $\mathrm{C} 3$ & $\mathrm{C} 4$ & $\mathrm{P}^{2}$ & $\mathrm{C} 1$ & $\mathrm{C} 2$ & C3 & $\mathrm{C} 4$ \\
\hline C1 & - & 0.50 & 0.70 & 0.70 & C1 & - & 0.90 & 0.70 & 0.50 \\
\hline$C 2$ & 0.84 & - & 0.90 & 0.90 & $\mathrm{C} 2$ & 0.70 & - & 0.70 & 0.50 \\
\hline C3 & 0.90 & 0.50 & - & 0.50 & $\mathrm{C} 3$ & 0.90 & 0.84 & - & 0.69 \\
\hline C4 & 0.90 & 0.30 & 0.70 & - & C4 & 0.50 & 0.50 & 0.70 & - \\
\hline \multicolumn{5}{|l|}{$\begin{array}{l}\text { Decision } \\
\text { maker } 3\end{array}$} & \multicolumn{5}{|c|}{$\begin{array}{l}\text { Decision } \\
\text { maker } 4\end{array}$} \\
\hline$P^{3}$ & C1 & $\mathrm{C} 2$ & $\mathrm{C3}$ & $\mathrm{C} 4$ & $\mathrm{P}^{4}$ & $\mathrm{C} 1$ & $\mathrm{C2}$ & C3 & $\mathrm{C} 4$ \\
\hline C1 & - & 0.70 & 0.50 & 0.50 & $\mathrm{C} 1$ & - & 0.70 & 0.30 & 0.90 \\
\hline$C 2$ & 0.70 & - & 0.70 & 0.50 & $\mathrm{C} 2$ & 0.90 & - & 0.68 & 0.70 \\
\hline C3 & 0.50 & 0.70 & - & 0.90 & $\mathrm{C} 3$ & 0.70 & 0.86 & - & 0.70 \\
\hline C4 & 0.70 & 0.75 & 0.70 & - & C4 & 0.70 & 0.70 & 0.50 & - \\
\hline
\end{tabular}

Table 17 Third-round fuzzy preferences for equity sharing model

\begin{tabular}{|c|c|c|c|c|c|c|c|c|c|}
\hline \multicolumn{5}{|c|}{ Decision maker 1} & \multicolumn{5}{|c|}{ Decision maker 2} \\
\hline$P^{1}$ & $\mathrm{C} 1$ & $\mathrm{C} 2$ & $\mathrm{C} 3$ & $\mathrm{C} 4$ & $\overline{P^{2}}$ & C1 & $\mathrm{C} 2$ & $\mathrm{C} 3$ & $\mathrm{C} 4$ \\
\hline C1 & - & 0.50 & 0.70 & 0.70 & $\mathrm{C} 1$ & - & 0.90 & 0.70 & 0.76 \\
\hline$C 2$ & 0.84 & - & 0.90 & 0.90 & $C 2$ & 0.70 & - & 0.70 & 0.50 \\
\hline C3 & 0.90 & 0.50 & - & 0.50 & C3 & 0.90 & 0.84 & - & 0.69 \\
\hline C4 & 0.90 & 0.70 & 0.70 & - & $\mathrm{C} 4$ & 0.50 & 0.50 & 0.70 & - \\
\hline \multicolumn{5}{|c|}{ Decision maker 3} & \multicolumn{5}{|c|}{ Decision maker 4} \\
\hline $\mathrm{P}^{3}$ & $\mathrm{C} 1$ & $\mathrm{C} 2$ & C3 & $\mathrm{C} 4$ & $\overline{\mathrm{P}^{4}}$ & $\mathrm{C} 1$ & $\mathrm{C} 2$ & $\mathrm{C} 3$ & $\mathrm{C} 4$ \\
\hline C1 & - & 0.70 & 0.50 & 0.50 & $\mathrm{C} 1$ & - & 0.70 & 0.76 & 0.90 \\
\hline $\mathrm{C} 2$ & 0.70 & - & 0.70 & 0.50 & $\mathrm{C} 2$ & 0.90 & - & 0.68 & 0.70 \\
\hline C3 & 0.78 & 0.70 & - & 0.90 & C3 & 0.70 & 0.86 & - & 0.70 \\
\hline C4 & 0.70 & 0.75 & 0.70 & - & C4 & 0.70 & 0.70 & 0.50 & - \\
\hline
\end{tabular}

The CCL value for the second-round fuzzy preferences for the equity sharing model is 0.82 , less than the threshold. The third-round evaluation should be employed to attempt to reach the consensus-based fuzzy preferences. The third-round fuzzy preferences are given for the equity sharing model in Table 17.

The CCL of third-round fuzzy preferences is higher than the threshold, with a value of 0.86 for the equity sharing model. Thus, in the third round, the consensus-based fuzzy preferences are obtained for the equity sharing model. These results are also considered consensus-based evaluations of the equity sharing model.

Illustrating the impact-relation directions of consensus-based multidimensional due diligence for fintech-based financing alternatives of green energy investment projects (phase 2)

The first step of this section includes constructing the consensus-based membership, nonmembership, and hesitant degrees for spherical fuzzy sets. The normalized values of fuzzy preference relations are obtained with the boundaries of 
$0 \leq \mu_{p}^{2}(u)+v_{p}^{2}(u)+\pi_{p}^{2}(u) \leq 1$ for the membership, nonmembership, and hesitant degrees of spherical fuzzy sets. The normalized values are computed for all fintechbased financing alternatives, respectively. Table 18 shows the consensus-based membership, nonmembership, and hesitant degrees of spherical fuzzy sets for the revenue sharing model.

In the next step, the defuzzied relation matrix is developed. The following computation procedures of the spherical fuzzy DEMATEL are applied separately for fintechbased financing alternatives, and the calculation details of the revenue sharing model are presented below. Moreover, only the analysis results of the other three alternatives are indicated. Table 19 shows the details of the defuzzied relation matrix for the revenue sharing model.

The following step includes the calculation of the normalized relation matrix. The details of this matrix with respect to the revenue sharing model are given in Table 20.

Next, the total relation matrix is developed. Table 21 indicates the details of this matrix regarding the revenue sharing model.

In the following step, the cause, effects, and weights of the consensus-based multidimensional due diligence for fintech-based financing alternatives of green energy investment projects are calculated. Table 22 demonstrates the analysis results for fintech-based financing alternatives.

Table 22 indicates that, with respect to the revenue sharing model, the customer expectation (C2) is the most significant factor with the highest weight (0.279). Additionally, regarding the peer-to-business debt model, organizational competency (C3)

Table 18 Consensus-based membership, nonmembership, and hesitant degrees of spherical fuzzy sets for revenue sharing model

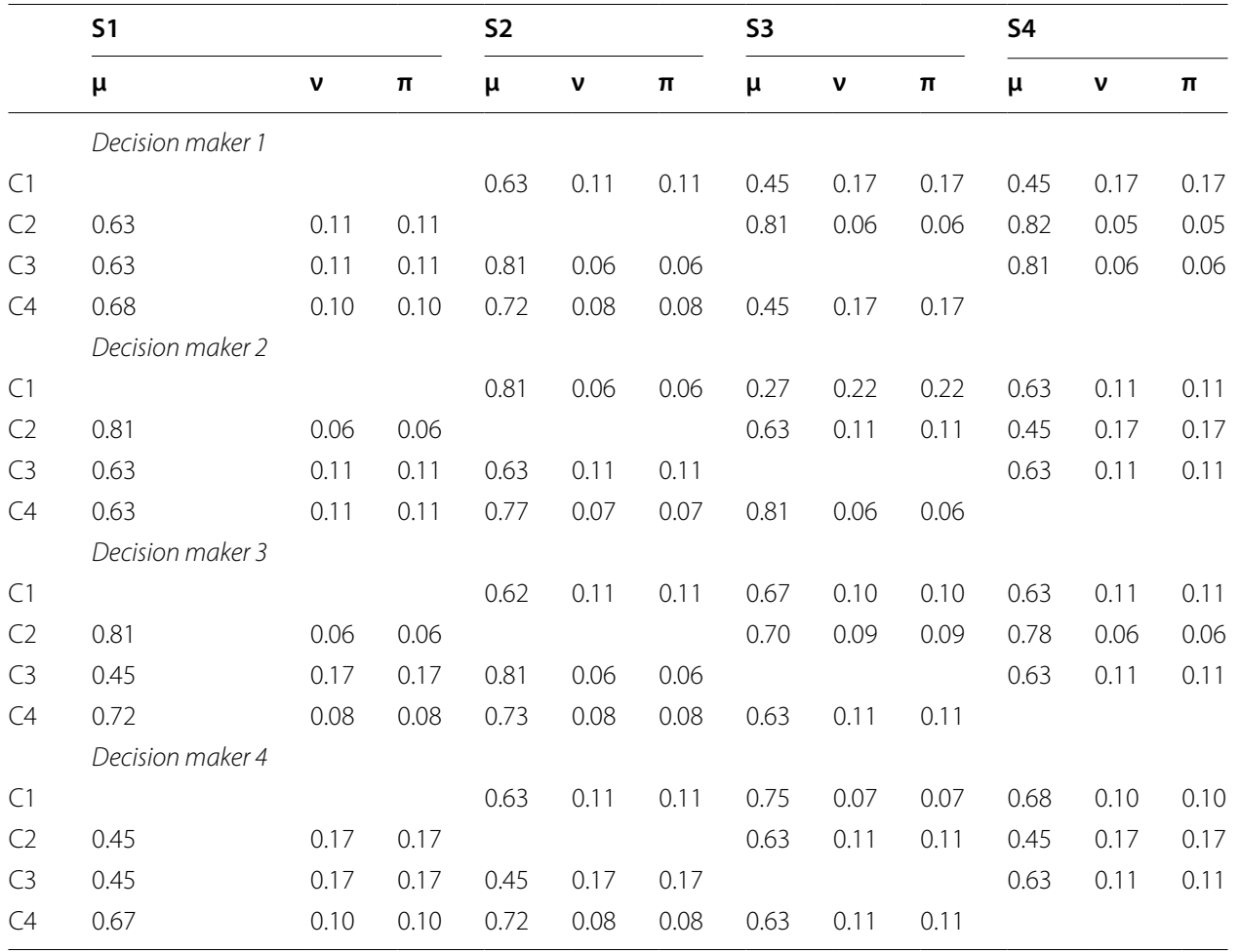


Table 19 Defuzzified relation matrix for revenue sharing model

\begin{tabular}{lllll}
\hline Criteria & C1 & C2 & C3 & C4 \\
\hline C1 & 0.000 & 0.350 & 0.207 & 0.241 \\
C2 & 0.385 & 0.000 & 0.375 & 0.333 \\
C3 & 0.173 & 0.385 & 0.000 & 0.352 \\
C4 & 0.336 & 0.429 & 0.306 & 0.000 \\
\hline
\end{tabular}

Table 20 Normalized relation matrix for revenue sharing model

\begin{tabular}{lllll}
\hline Criteria & C1 & C2 & C3 & C4 \\
\hline C1 & 0.000 & 0.320 & 0.189 & 0.220 \\
C2 & 0.352 & 0.000 & 0.343 & 0.304 \\
C3 & 0.158 & 0.352 & 0.000 & 0.322 \\
C4 & 0.307 & 0.392 & 0.280 & 0.000 \\
\hline
\end{tabular}

Table 21 Total relation matrix for revenue sharing model

\begin{tabular}{lllll}
\hline Criteria & C1 & C2 & C3 & C4 \\
\hline C1 & 1.524 & 2.072 & 1.671 & 1.725 \\
C2 & 2.183 & 2.318 & 2.164 & 2.189 \\
C3 & 1.862 & 2.331 & 1.709 & 1.993 \\
C4 & 2.152 & 2.589 & 2.119 & 1.945 \\
\hline
\end{tabular}

plays the most important role. However, financial return (C1) is found to be the most crucial criterion with respect to the equity sharing model. Finally, customer expectation $(\mathrm{C} 2)$ has the greatest importance as per the rewarding model. Furthermore, the directions are constructed among the criteria by the fintech-based financing alternatives. The averaged values of the total relation matrix are considered to be the threshold, and the higher values than the threshold demonstrate an impact of the criterion as stated in the row on the criterion for the column. Accordingly, the impact directions of the criteria are illustrated by the fintech-based financing alternatives. Figure 3 explains the details of the revenue sharing model.

Figure 3 illustrates that market competency is the most influencing criterion regarding the revenue sharing model. However, customer expectation is also identified as the most influenced item. The impact-relation map for the business debt model is shown in Fig. 4.

Figure 4 demonstrates that financial returns are the most influenced criterion. Moreover, a mutual relationship exists between customer expectation and organizational competency with respect to the business debt model. Moreover, the impactrelation map for the equity sharing model is illustrated in Fig. 5.

Figure 5 shows that financial returns is the most affected item, whereas organizational competency has an influence on the other three criteria. Finally, the impactrelation map regarding the rewarding model is indicated in Fig. 6. 
Table 22 Total cause, effect, and weights of multidimensional due diligence with consensus for fintech-based financing alternatives

\begin{tabular}{llllll}
\hline Criteria & D & E & D+E & D-E & Weights \\
\hline Revenue sharing model & & & & & \\
Financial returns (Criterion 1) & 6.993 & 7.721 & 14.714 & -0.728 & 0.226 \\
Customer expectations (Criterion 2) & 8.854 & 9.311 & 18.165 & -0.456 & 0.279 \\
Organizational competency (Criterion 3) & 7.895 & 7.664 & 15.559 & 0.231 & 0.239 \\
Market competency (Criterion 4) & 8.805 & 7.852 & 16.656 & 0.953 & 0.256 \\
Peer to business debt model & & & & & \\
Financial returns (Criterion 1) & 3.303 & 5.414 & 8.718 & -2.111 & 0.250 \\
Customer expectations (Criterion 2) & 5.032 & 3.984 & 9.015 & 1.048 & 0.258 \\
Organizational competency (Criterion 3) & 4.636 & 4.548 & 9.184 & 0.088 & 0.263 \\
Market competency (Criterion 4) & 4.498 & 3.524 & 8.021 & 0.974 & 0.230 \\
Equity sharing model & & & & & \\
Financial returns (Criterion 1) & 5.303 & 6.633 & 11.937 & -1.330 & 0.266 \\
Customer expectations (Criterion 2) & 6.018 & 5.387 & 11.404 & 0.631 & 0.254 \\
Organizational competency (Criterion 3) & 6.378 & 5.009 & 11.388 & 1.369 & 0.253 \\
Market competency (Criterion 4) & 4.780 & 5.450 & 10.229 & -0.670 & 0.228 \\
Rewarding model & & & & & \\
Financial returns (Criterion 1) & 1.689 & 2.261 & 3.949 & -0.572 & 0.241 \\
Customer expectations (Criterion 2) & 2.790 & 2.087 & 4.876 & 0.703 & 0.297 \\
Organizational competency (Criterion 3) & 1.759 & 1.807 & 3.567 & -0.048 & 0.217 \\
Market competency (Criterion 4) & 1.962 & 2.045 & 4.006 & -0.083 & 0.244 \\
\hline
\end{tabular}

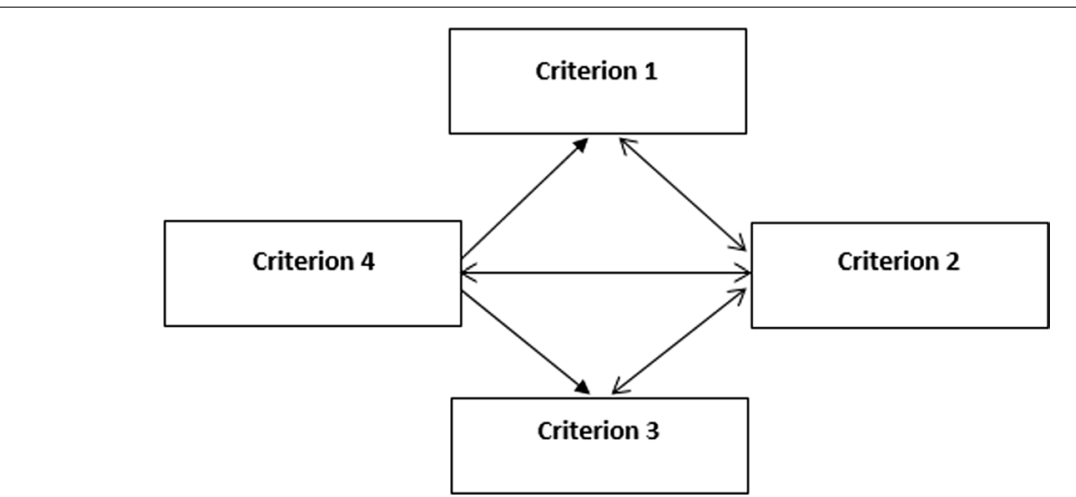

Fig. 3 Impact-relation directions of consensus-based multidimensional due diligence for revenue sharing model

Figure 6 illustrates that all criteria have a significant impact on financial returns. Moreover, a bidirectional relationship is also identified between customer expectation and market competency.

\section{Conclusion and discussion}

This study aimed to evaluate the multidimensional due diligence of fintech-based financial alternatives for green energy investment projects. In this context, a novel model was generated that consisted of two different phases. The first phase was related to the construction of the consensus results of multidimensional due diligence for fintechbased financing alternatives of green energy investment projects. For this purpose, a 


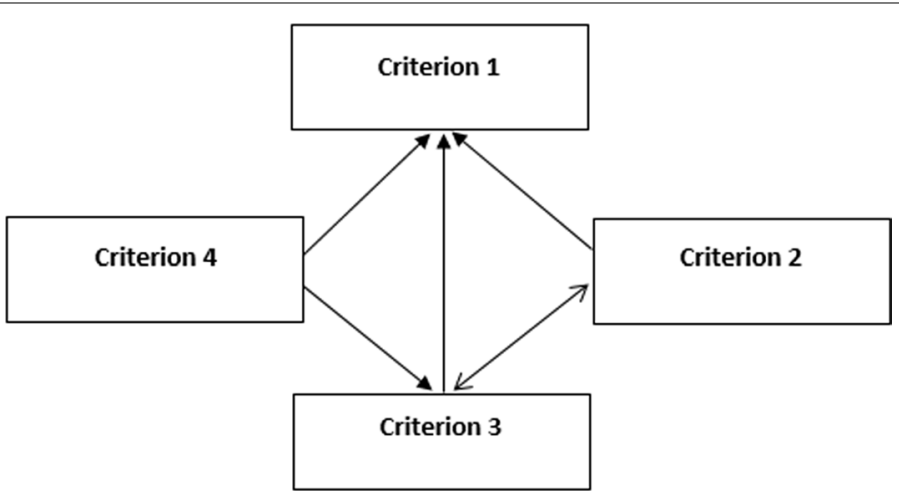

Fig. 4 Impact-relation directions of consensus-based multidimensional due diligence for peer-to-business debt model

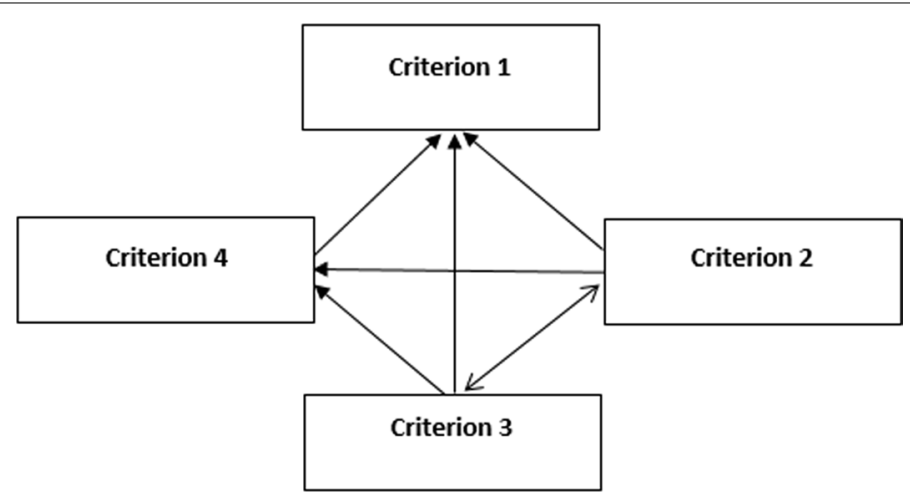

Fig. 5 Impact-relation directions of consensus-based multidimensional due diligence for equity sharing model

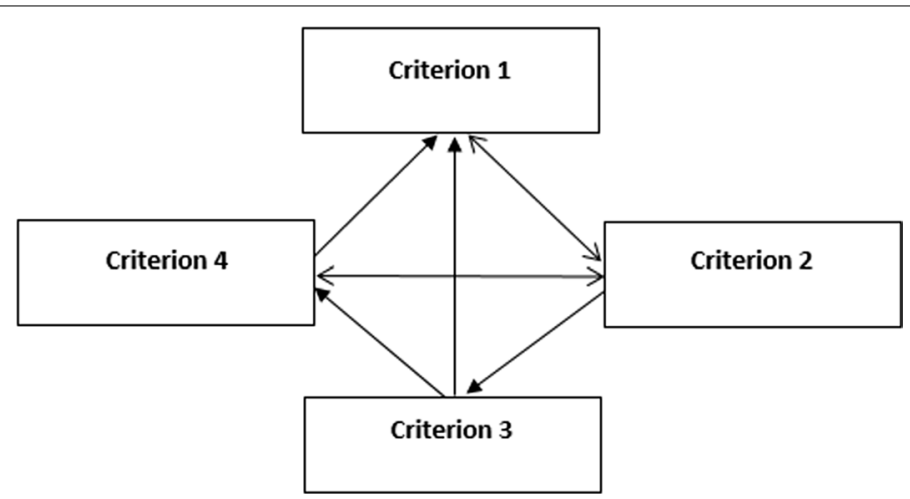

Fig. 6 Impact-relation directions of consensus-based multidimensional due diligence for rewarding model

consensus-based group decision-making methodology was considered. The second phase included an illustration of the impact-relation directions of consensus-based multidimensional due diligence for fintech-based financing alternatives of green energy investment projects. During this process, the weights of the criteria were identified using spherical fuzzy DEMATEL. The conclusion reached is that customer expectation is the 
most essential factor regarding the revenue sharing and rewarding models. Moreover, organizational competency was determined to play the most important role with respect to the peer-to-business debt model. In addition, financial return had the greatest importance for the equity sharing model.

Obviously, green energy investors should prioritize customer satisfaction if they prefer the revenue sharing and rewarding models as fintech-based financing alternatives. The aim of the revenue sharing model was to distribute the total income among shareholders. Additionally, in the rewarding model, the projects' products and services were provided with preorder prices. For these two models, ensuring that investors contribute to the project is very important. In this context, investors seem to pay attention to the extent to which companies meet customer expectations. The image of companies that can provide customer satisfaction will increase positively. This positive image will help companies more easily find the financing they need. In this context, green energy investors must first conduct a detailed analysis that can clearly determine customer expectations. Next, actions that can best satisfy these customer expectations must be determined and implemented. In this way, green energy companies become more preferred by customers, which will help more easily obtain financing sources through revenue sharing and rewarding models. Li et al. (2021) aimed to evaluate the strategic priorities of customer expectations for green energy investments. For this purpose, TRIZ-based factors are considered. The results found using the interval type-2 fuzzy DEMATEL showed that providing customer satisfaction has a crucial role in increasing the effectiveness of green energy investments. Additionally, Ubay and Karakuş (2020a, b), Chamandoust et al. (2020), and Lee and Shepley (2020) highlighted the significance of meeting customer expectations for the sustainable performance of green energy investments.

In addition, if the aim of green energy investment companies is to find financial sources using the peer-to-business debt model, they should focus on improving organizational competency. In this context, the peer-to-business debt model refers to borrowing with a risk premium. The biggest disadvantage of this method is that debt and interest payments have to be made even if the project fails. Therefore, green energy companies that prefer to find financing resources using this method should pay attention to the organizational effectiveness within the institution, which will contribute to both easily finding funds and easier payment of the borrowed amount through this method. For this purpose, the consistency of personnel and other organizational assets for the strategic success of projects should be improved. In the literature, Tantau and Staiger (2020) and Zhou et al. (2020) also underlined the importance of organizational effectiveness for improvements to green energy investment projects. Moreover, if green energy companies believe that equity sharing is the best model for fintech-based financing alternatives, they should attempt to increase their financial returns. Investors pay attention to the profitability of a green energy company when deciding to become a partner. In this context, for green energy investment companies that want to prefer this method to focus on cost efficiency would be appropriate. The importance of financial effectiveness for developing green energy investment projects was emphasized in the literature by different researchers (Schabek 2020; Rastogi et al. 2020).

The most significant contribution of this study is to identify the important points for green energy investment companies according to different fintech-based financing 
alternatives using a novel model that considers consensus and spherical fuzzy DEMATEL approaches. Therefore, appropriate strategies can be defined for different financing alternatives. Nonetheless, the main limitation of this study is a general focus on green energy investments. However, different types of green energy alternatives exist, such as wind, solar, and geothermal. Therefore, in future studies, more specific evaluations can be conducted based on different green energy alternatives. This situation provides the opportunity to identify more specific strategies.

\section{Authors' contributions}

WL conducted a literature evaluation and made statistical analysis. YS made statistical analysis and participated in its design and coordination. SY participated in the design of the study and performed the statistical analysis. HD conceived of the study and participated in its design and coordination and helped to draft the manuscript. All authors read and approved the final manuscript.

\section{Funding}

This work was sponsored by the Philosophy and Social Science Planning Project of Guangdong Province (Grant No. GD20YGL12), Basic and Applied Basic Project of Guangzhou City (Grant No. 202102020629), Philosophy and Social Science Planning Project of Guangzhou City (Grant No. 2021GZGJ48), National Natural Science Foundation of China (Grant No. 71771058).

\section{Availability of data and materials}

In this study, 4 different experts made evaluations about the criteria. These evaluations are considered as input data in the study. The data used to support the findings of this study are included within the article.

\section{Declarations}

\section{Competing interests}

The authors declare that they have no competing interests.

Received: 16 February 2021 Accepted: 20 August 2021

Published online: 02 December 2021

\section{References}

Ali Z, Mahmood T, Yang MS (2020a) Complex T-spherical fuzzy aggregation operators with application to multi-attribute decision making. Symmetry 12(8):1311

Ali Z, Mahmood T, Yang MS (2020b) TOPSIS method based on complex spherical fuzzy sets with Bonferroni mean operators. Mathematics 8(10):1739

Alkan Ö, Albayrak ÖK (2020) Ranking of renewable energy sources for regions in Turkey by fuzzy entropy based fuzzy COPRAS and fuzzy MULTIMOORA. Renew Energy 162:712-726

Alzoubi ESS (2018) Audit quality, debt financing, and earnings management: evidence from Jordan. J Int Account Audit Tax 30:69-84

Anshari M, Almunawar MN, Masri M, Hamdan M (2019) Digital marketplace and FinTech to support agriculture sustainability. Energy Proc 156:234-238

Ashraf S, Abdullah S (2019) Spherical aggregation operators and their application in multiattribute group decisionmaking. Int J Intell Syst 34(3):493-523

Ashraf S, Abdullah S, Mahmood T, Ghani F, Mahmood T (2019) Spherical fuzzy sets and their applications in multi-attribute decision making problems. J Intell Fuzzy Syst 36(3):2829-2844

Atanassov KT (1999) Intuitionistic fuzzy sets. In: Intuitionistic fuzzy sets, pp 1-137. Physica, Heidelberg

Basilio MP, de Freitas JG, Kämpffe MGF, Rego RB (2018) Investment portfolio formation viamulticriteria decision aid: a Brazilian stock market study. J Model Manag 13(2):394-417

Benková E, Gallo P, Balogová B, Nemec J (2020) Factors affecting the use of balanced scorecard in measuring company performance. Sustainability 12(3):1178

Bertheau P (2020) Supplying not electrified islands with 100\% renewable energy based micro grids: a geospatial and techno-economic analysis for the Philippines. Energy 202:117670

Best R (2017) Switching towards coal or renewable energy? The effects of financial capital on energy transitions. Energy Econ 63:75-83

Boot A, Hoffmann P, Laeven L, Ratnovski L (2021) Fintech: what's old, what's new? J Financ Stab 53:100836

Boratyńska K (2019) Impact of digital transformation on value creation in Fintech services: an innovative approach. J Promot Manag 25(5):631-639

Bu Y, Li H, Wu X (2021) Effective regulations of FinTech innovations: the case of China. Econ Innov New Technol. https:// doi.org/10.1080/10438599.2020.1868069.

Chamandoust H, Derakhshan G, Hakimi SM, Bahramara S (2020) Tri-objective scheduling of residential smart electrical distribution grids with optimal joint of responsive loads with renewable energy sources. J Energy Stor 27:101112 
Chang K, Zeng Y, Wang W, Wu X (2019) The effects of credit policy and financial constraints on tangible and research \& development investment: firm-level evidence from China's renewable energy industry. Energy Policy 130:438-447

Cuong BC, Kreinovich V (2013 Picture fuzzy sets-a new concept for computational intelligence problems. In: 2013 third world congress on information and communication technologies (WICT 2013), pp 1-6. IEEE

Degerli K (2019) Regulatory challenges and solutions for fintech in Turkey. Proc Comput Sci 158:929-937

Delen D, Dorokhov O, Dorokhova L, Dinçer H, Yüksel S (2020) Balanced scorecard-based analysis of customer expectations for cosmetology services: a hybrid decision modeling approach. J Manag Anal 7(4):532-563

Dinçer H, Yüksel S (2018) Comparative evaluation of BSC-based new service development competencies in Turkish banking sector with the integrated fuzzy hybrid MCDM using content analysis. Int J Fuzzy Syst 20(8):2497-2516

Dinçer H, Yüksel S (2019a) An integrated stochastic fuzzy MCDM approach to the balanced scorecard-based service evaluation. Math Comput Simul 166:93-112

Dinçer H, Yüksel S (2019b) Multidimensional evaluation of global investments on the renewable energy with the integrated fuzzy decision-making model under the hesitancy. Int J Energy Res 43(5):1775-1784

Dinçer H, Hacıoğlu Ü, Yüksel S (2017) Balanced scorecard based performance measurement of European airlines using a hybrid multicriteria decision making approach under the fuzzy environment. J Air Transp Manag 63:17-33

Dinçer H, Yüksel S, Martinez L (2019) Analysis of balanced scorecard-based SERVQUAL criteria based on hesitant decisionmaking approaches. Comput Ind Eng 131:1-12

Dincer $\mathrm{H}$ (2019) $\mathrm{HHI}$-based evaluation of the European banking sector using an integrated fuzzy approach. Kybernetes 48(6):1195-1215

Dong Y, Zha Q, Zhang H, Kou G, Fujita H, Chiclana F, Herrera-Viedma E (2018) Consensus reaching in social network group decision making: research paradigms and challenges. Knowl-Based Syst 162:3-13

Dorfleitner, G., Hornuf, L., Schmitt, M., \& Weber, M. (2017). Definition of FinTech and description of the FinTech industry. In FinTech in Germany (pp. 5-10). Springer, Cham.

Dorfleitner G, Hornuf L, Schmitt M, Weber M (2017) The fintech market in Germany. In: FinTech in Germany, pp 13-46. Springer, Cham

Egli F, Steffen B, Schmidt TS (2018) A dynamic analysis of financing conditions for renewable energy technologies. Nat Energy 3(12):1084-1092

Ekel PY (2002) Fuzzy sets and models of decision making. Comput Math Appl 44(7):863-875

Fang S, Zhou P, Dinçer H, Yüksel S (2021) Assessment of safety management system on energy investment risk using house of quality based on hybrid stochastic interval-valued intuitionistic fuzzy decision-making approach. Saf Sci 141:105333

Fenwick M, McCahery JA, Vermeulen EP (2018) Fintech and the financing of SMEs and entrepreneurs: from crowdfunding to marketplace lending. In: The economics of crowdfunding, pp. 103-129. Palgrave Macmillan, Cham

Fianto BA, Gan C, Hu B, Roudaki J (2018) Equity financing and debt-based financing: evidence from Islamic microfinance institutions in Indonesia. Pac Basin Financ J 52:163-172

Fosso Wamba S, Kala Kamdjoug JR, Epie Bawack R, Keogh JG (2020) Bitcoin, Blockchain and Fintech: a systematic review and case studies in the supply chain. Prod Plan Control 31(2-3):115-142

Geddes A, Schmidt TS, Steffen B (2018) The multiple roles of state investment banks in low-carbon energy finance: An analysis of Australia, the UK and Germany. Energy Policy 115:158-170

Gimpel H, Rau D, Röglinger M (2018) Understanding FinTech start-ups-a taxonomy of consumer-oriented service offerings. Electron Mark 28(3):245-264

Gomber P, Kauffman RJ, Parker C, Weber BW (2018) On the fintech revolution: interpreting the forces of innovation, disruption, and transformation in financial services. J Manag Inf Syst 35(1):220-265

Gozman D, Liebenau J, Mangan J (2018) The innovation mechanisms of fintech start-ups: insights from SWIFT's innotribe competition. J Manag Inf Syst 35(1):145-179

Grafström J, Söderholm P, Gawel E, Lehmann P, Strunz S (2020) Government support to renewable energy R\&D: drivers and strategic interactions among EU Member States. Econ Innov New Technol. https://doi.org/10.1080/10438599. 2020.1857499

Harish AR, Liu XL, Zhong RY, Huang GQ (2021) Log-flock: a blockchain-enabled platform for digitalasset valuation and risk assessment in E-commerce logistics financing. Comput Ind Eng 151:107001

Heuër A (2017) Women-to-women entrepreneurial energy networks: a pathway to green energy uptake at the base of pyramid. Sustain Energy Technol Assess 22:116-123

Hu Y, Xiao S, Wen J, Li J (2019a) An ANP-multi-criteria-based methodology to construct maintenance networks for agricultural machinery cluster in a balanced scorecard context. Comput Electron Agric 158:1-10

Hu Z, Ding S, Li S, Chen L, Yang S (2019b) Adoption intention of fintech services for bank users: an empirical examination with an extended technology acceptance model. Symmetry 11(3):340

Hughes L, Meckling J (2017) The politics of renewable energy trade: the US-China solar dispute. Energy Policy 105:256-262

Ilbahar E, Karaşan A, Cebi S, Kahraman C (2018) A novel approach to risk assessment for occupational health and safety using Pythagorean fuzzy AHP \& fuzzy inference system. Saf Sci 103:124-136

Iryna S, Tetiana K, Vitalii D, Yevgen K (2020) Green energy projects in households and its financial support in Ukraine. Int J Sustain Energy 39(3):218-239

Jagtiani J, Lemieux C (2019) The roles of alternative data and machine learning in fintech lending: evidence from the LendingClub consumer platform. Financ Manag 48(4):1009-1029

Jan N, Ali Z, Ullah K, Mahmood T (2019) Some generalized distance and similarity measures for picture hesitant fuzzy sets and their applications in building material recognition and multi-attribute decision making. Punjab Univ J Math 51(7):51-70

Janbazi S, Mandejin MRR, Eslambulchi A (2019) Designing a comprehensive evaluation model for health system reform plan in Iran: an approach to extended balanced scorecard. Novelty Biomed 7(4):187-200

Jin J, Wan X, Lin Y, Kuang F, Ning J (2019) Public willingness to pay for the research and development of solar energy in Beijing, China. Energy Policy 134:110962 
Jun Q, Dinçer H, Yüksel S (2021) Stochastic hybrid decision-making based on interval type 2 fuzzy sets formeasuring the innovation capacities of financial institutions. Int J Financ Econ 26(1):573-593

Kalkavan H, Halim Baş IE, Eti S, Yüksel S (2021) Defining appropriate government strategies to reduce unemployment during COVID-19 pandemics. Management Strategies to Survive in a Competitive Environment: How to Improve Company Performance, 155

Karimi H, Ekşioğlu SD, Khademi A (2018) Analyzing tax incentives for producing renewable energy by biomass cofiring. IISE Trans 50(4):332-344

Karun Kumar Y, Kesava Rao VVS (2020) Development of balanced score card framework for performance evaluation of airlines. Int J Manag (IJM) 10(6):2019

Khairat GM (2017) The balanced scorecard approach as a tool for performance evaluation in the airline companies. Int J Heritage Tourism Hosp 10(2/2)

Khan B, Singh P (2017) The current and future states of Ethiopia's energy sector and potential for green energy: a comprehensive study. Int J Eng Res Afr 33:115-139

Kou G, Akdeniz ÖO, Dinçer H, Yüksel S (2021) Fintech investments in European banks: a hybrid IT2 fuzzy multidimensional decision-making approach. Financ Innov 7(1):1-28

Kutan AM, Paramati SR, Ummalla M, Zakari A (2018) Financing renewable energy projects in major emerging market economies: Evidence in the perspective of sustainable economic development. Emerg Mark Financ Trade 54(8):1761-1777

Kutlu Gündoğdu F, Kahraman C (2019) Spherical fuzzy sets and spherical fuzzy TOPSIS method. J Intell Fuzzy Syst 36(1):337-352

Lee J, Shepley MM (2020) Benefits of solar photovoltaic systems for low-income families in social housing of Korea: renewable energy applications as solutions to energy poverty. J Build Eng 28:101016

Lee I, Shin YJ (2018) Fintech: Ecosystem, business models, investment decisions, and challenges. Bus Horiz 61(1):35-46

Lee KM (2000) Bipolar-valued fuzzy sets and their operations. In: Proc. int. conf. on intelligent technologies, Bangkok, Thailand, 2000, pp 307-312

Leksono EB, Suparno S, Vanany I (2019) Integration of a balanced scorecard, DEMATEL, and ANP for measuring the performance of a sustainable healthcare supply chain. Sustainability 11(13):3626

Li F, Qiu Z, Zhang J, Liu C, Cai Y, Xiao M (2017) Spatial distribution and fuzzy health risk assessment of trace elements in surface water from Honghu Lake. Int J Environ Res Public Health 14(9):1011

Li X, Zhu S, Yüksel S, Dinçer H, Ubay GG (2020) Kano-based mapping of innovation strategies for renewable energy alternatives using hybrid interval type-2 fuzzy decision-making approach. Energy 211:118679

Li YX, Wu ZX, Dinçer H, Kalkavan H, Yüksel S (2021) Analyzing TRIZ-based strategic priorities of customer expectations for renewable energy investments with interval type-2 fuzzy modeling. Energy Rep 7:95-108

Liang D, Zhang Y, Xu Z, Jamaldeen A (2019) Pythagorean fuzzy VIKOR approaches based on TODIM for evaluating internet banking website quality of Ghanaian banking industry. Appl Soft Comput 78:583-594

Liu P, Pedrycz W (2020) Consistency-and consensus-based group decision-making method with incomplete probabilistic linguistic preference relations. IEEE Trans Fuzzy Syst. https://doi.org/10.1109/TFUZZ.2020.3003501

Lyu X, Shi A (2018) Research on the renewable energy industry financing efficiency assessment and mode selection. Sustainability 10(1):222

Mahmood T, Ullah K, Khan Q, Jan N (2019) An approach toward decision-making and medical diagnosis problems using the concept of spherical fuzzy sets. Neural Comput Appl 31(11):7041-7053

Mahmood T, Ali Z (2020) The fuzzy cross-entropy for picture hesitant fuzzy sets and their application in multi criteria decision making. Punjab Univ J Math 52(10)

Mahmood T (2020) A novel approach towards bipolar soft sets and their applications. J Math 2020

Marqués Marzal Al, García V, Sánchez Garreta JS (2020) Ranking-based MCDM models in financial management applications: analysis and emerging challenges. Prog Artif Intell 9:171-193

Mathew M, Chakrabortty RK, Ryan MJ (2020) A novel approach integrating AHP and TOPSIS under spherical fuzzy sets for advanced manufacturing system selection. Eng Appl Artif Intell 96:103988

Mazzucato M, Semieniuk G (2018) Financing renewable energy: who is financing what and why it matters. Technol Forecast Soc Chang 127:8-22

Meng Y, Dinçer H, Yüksel S (2021a) TRIZ-based green energy project evaluation using innovation life cycle and fuzzy modeling. IEEE Access 9:69609-69625

Meng Y, Wu H, Zhao W, Chen W, Dinçer H, Yüksel S (2021b) A hybrid heterogeneous Pythagorean fuzzy group decision modelling for crowdfunding development process pathways of fintech-based clean energy investment projects. Financ Innov 7(1):1-34

Mirzania P, Ford A, Andrews D, Ofori G, Maidment G (2019) The impact of policy changes: the opportunities of Community Renewable Energy projects in the UK and the barriers they face. Energy Policy 129:1282-1296

Mitkova V, Mlynarovič V (2019) Investment opportunities identification based on macroeconomic development, the multiple criteria decision approach. Symmetry 11(6):827

Molodtsov D (1999) Soft set theory-first results. Comput Math Appl 37(4-5):19-31

Moraga JA, Quezada LE, Palominos PI, Oddershede AM, Silva HA (2020) A quantitative methodology to enhance a strategy map. Int J Prod Econ 219:43-53

Nilashi M, Samad S, Manaf AA, Ahmadi H, Rashid TA, Munshi A, Almukadi W, Ibrahim O, Ahmed OH (2019) Factors influencing medical tourism adoption in Malaysia: a DEMATEL-Fuzzy TOPSIS approach. Comput Ind Eng 1(137):106005

Opeyemi A, Uchenna E, Simplice A, Evans O (2019) Renewable energy, trade performance and the conditional role of finance and institutional capacity in sub-Sahara African countries. Energy Policy 132:490-498

Owusu A (2017) Business intelligence systems and bank performance in Ghana: the balanced scorecard approach. Cogent Bus Manag 4(1):1364056

Pawlak Z (1982) Rough sets. Int J Comput Inform Sci 11(5):341-356

Pedrycz W (1990) Fuzzy sets in pattern recognition: methodology and methods. Pattern Recogn 23(1-2):121-146 
Plutshack V, Sengupta S, Sahay A, Viñuales JE (2019) New and renewable energy social enterprises accessing government support: findings from India. Energy Policy 132:367-378

Polzin F, Egli F, Steffen B, Schmidt TS (2019) How do policies mobilize private finance for renewable energy? —A systematic review with an investor perspective. Appl Energy 236:1249-1268

Qin J, Xi Y, PedryczW (2020) Failure mode and effects analysis (FMEA) for risk assessment based on interval type-2 fuzzy evidential reasoning method. Appl Soft Comput 89:106134

Qiu D, Dinçer H, Yüksel S, Ubay GG (2020) Multi-faceted analysis of systematic risk-based wind energy investment decisions in E7 economies using modified hybrid modeling with IT2 fuzzy sets. Energies 13(6):1423

Rahimi H, Kavosi Z, Shojaei P, Kharazmi E (2017) Key performance indicators in hospital based on balanced scorecard model. J Health Manag Inform 4(1):17-24

Rajak M, Shaw K (2019) Evaluation and selection of mobile health (mHealth) applications using AHP and fuzzy TOPSIS. Technol Soc 59:101186

Rastogi R, Jaiswal R, Jaiswal RK (2020) Renewable energy firm's performance analysis using machine learning approach. Proc Comput Sci 175:500-507

Riaz M, Hashmi MR (2019) Linear Diophantine fuzzy set and its applications towards multi-attribute decision-making problems. J Intell Fuzzy Syst 37(4):5417-5439

Riaz M, Garg H, Farid HMA, Chinram R (2021) Multi-criteria decision making based on bipolar picture fuzzy operators and new distance measures. Comput Model Eng Sci 127(2):771-800

Sangroya D, Nayak JK (2017) Factors influencing buying behaviour of green energy consumer. J Clean Prod 151:393-405

Sarkodie SA, Ajmi AN, Adedoyin FF, Owusu PA (2021) Econometrics of anthropogenic emissions, green energy-based innovations, and energy intensity across OECD countries. Sustainability 13(8):4118

SchabekT (2020) The financial performance of sustainable power producers in emerging markets. Renew Energy 160:1408-1419

Shabir M, Naz M (2013) On bipolar soft sets. arXiv preprint arXiv:1303.1344

Steffen B (2018) The importance of project finance for renewable energy projects. Energy Econ 69:280-294

Stucki T (2019) Which firms benefit from investments in green energy technologies? The effect of energy costs. Res Policy 48(3):546-555

Sun Y, Li M, Zhang M, Khan HSUD, Li J, Li Z, Sun H, Zhu Y, Anaba OA (2021) A study on China's economic growth, green energy technology, and carbon emissions based on the Kuznets curve (EKC). Environ Sci Pollut Res 28(6):7200-7211

Suroso A, Tandra H, Syaukat Y, Najib M (2021) The issue in Indonesian palm oil stock decision making: sustainable and risk criteria. Dec Sci Lett 10(3):241-246

Sweerts B, Dalla Longa F, van der Zwaan B (2019) Financial de-risking to unlock Africa's renewable energy potential. Renew Sustain Energy Rev 102:75-82

Taghizadeh-Hesary F, Mortha A, Farabi-Asl H, Sarker T, Chapman A, Shigetomi Y, Fraser T (2020) Role of energy finance in geothermal power development in Japan. Int Rev Econ Financ 70:398-412

Tan RR, Aviso KB, Ng DKS (2019) Optimization models for financing innovations in green energy technologies. Renew Sustain Energy Rev 113:109258

Tantau A, Staiger R (2020) Business models in renewable energy industry. In: Sustainable business: concepts, methodologies, tools, and applications, pp 318-348. IGI Global

Teo TT, Logenthiran T, Woo WL, Abidi K, John T, Wade NS, Taylor PC (2020) Optimization of fuzzy energy-management system for grid-connected microgrid using NSGA-II. IEEE Trans Cybern. https://doi.org/10.1109/TCYB.2020.3031109

Thangaramya K, Kulothungan K, Logambigai R, Selvi M, Ganapathy S, Kannan A (2019) Energy aware cluster and neurofuzzy based routing algorithm for wireless sensor networks in loT. Comput Netw 151:211-223

Tian C, Peng J, Zhang W, Zhang S, Wang J (2020) Tourism environmental impact assessment based on improved AHP and picture fuzzy PROMETHEE II methods. Technol Econ Dev Econ 26(2):355-378

Ubay GG, Karakuş H (2020) The role of technology-based renewable energy investments on macroeconomic stability. In Strategic outlook for innovative work behaviours, pp 119-130. Springer, Cham

Ullah K, Mahmood T, Jan N, Ahmad Z (2020) Policy decision making based on some averaging aggregation operators of t-spherical fuzzy sets; a multi-attribute decision making approach. Ann Optim Theory Pract 3(3):69-92

Vand B, Hast A, Bozorg S, Li Z, Syri S, Deng S (2019) Consumers'attitudes to support green energy: a case study in Shanghai. Energies 12(12):2379

Wang J, Kumbasar T (2019) Parameter optimization of interval Type-2 fuzzy neural networks based on PSO and BBBC methods. IEEE/CAA J Autom Sin 6(1):247-257

Wu L, Wei G, Gao H, Wei Y (2018) Some interval-valued intuitionistic fuzzy Dombi Hamy mean operators and their application for evaluating the elderly tourism service quality in tourism destination. Mathematics 6(12):294

Xu XH, Du ZJ, Chen XH, Cai CG (2019) Confidence consensus-based model for large-scale group decision making: a novel approach to managing non-cooperative behaviors. Inf Sci 477:410-427

Yang C, Lan S, Huang GQ (2019a) Revenue sharing model in New Hong Kong's warehousing business paradigm. J Ambient Intell Humaniz Comput 10(3):883-892

Yang X, He L, Xia Y, Chen Y (2019b) Effect of government subsidies on renewable energy investments: the threshold effect. Energy Policy 132:156-166

Yao JFF, Yao JS (2001) Fuzzy decision making for medical diagnosis based on fuzzy number and compositional rule of inference. Fuzzy Sets Syst 120(2):351-366

Yuan J, Zhang ZM, Yüksel S, Dinçer H (2020) Evaluating recognitive balanced scorecard-based quality improvement strategies of energy investments with the integrated hesitant 2-tuple interval-valued Pythagorean fuzzy decisionmaking approach to QFD. IEEE Access 8:171112-171128

Yuan G, Xie F, Dinçer H, Yüksel S (2021) The theory of inventive problem solving (TRIZ)-based strategic mapping of green nuclear energy investments with spherical fuzzy group decision-making approach. Int J Energy Res. https://doi. org/10.1002/er.6435 
Zadeh LA (1996) Fuzzy sets. In: Fuzzy sets, fuzzy logic, and fuzzy systems: selected papers by Lotfi A Zadeh, pp 394-432

Zha Q, Kou G, Zhang H, Liang H, Chen X, Li CC, Dong Y (2020) Opinion dynamics in finance and business: a literature review and research opportunities. Financ Innov 6(1):1-22

Zhang F (2020) Leaders and followers in finance mobilization for renewable energy in Germany and China. Environ Innov Soc Trans 37:203-224

Zhang H, Dong Y, Palomares-Carrascosa I, Zhou H (2018) Failure mode and effect analysis in a linguistic context: a consensus-based multiattribute group decision-making approach. IEEE Trans Reliab 68(2):566-582

Zhang H, Dong Y, Chiclana F, Yu S (2019) Consensus efficiency in group decision making: a comprehensive comparative study and its optimal design. Eur J Oper Res 275(2):580-598

Zhang G, Zhou S, Xia X, Yüksel S, Baş H, Dincer H (2020) Strategic mapping of youth unemployment with interval-valued intuitionistic hesitant fuzzy DEMATEL based on 2-tuple linguistic values. IEEE Access 8:25706-25721

Zhao Y, Xu Y, Yüksel S, Dinçer H, Ubay GG (2021) Hybrid IT2 fuzzy modelling with alpha cuts for hydrogen energy investments. Int J Hydrogen Energy 46(13):8835-8851

Zhong J, Hu X, Yüksel S, Dinçer H, Ubay GG (2020) Analyzing the investments strategies for renewable energies based on multi-criteria decision model. IEEE Access 8:118818-118840

Zhou P, Zhou P, Yüksel S, Dinçer H, Uluer GS (2020) Balanced scorecard-based evaluation of sustainable energy investment projects with it2 fuzzy hybrid decision making approach. Energies 13(1):82

\section{Publisher's Note}

Springer Nature remains neutral with regard to jurisdictional claims in published maps and institutional affiliations.

\section{Submit your manuscript to a SpringerOpen ${ }^{\circ}$ journal and benefit from:}

- Convenient online submission

- Rigorous peer review

- Open access: articles freely available online

- High visibility within the field

Retaining the copyright to your article

Submit your next manuscript at $\gg$ springeropen.com 